3

\title{
Electrospinning Technology for Nanofibrous Scaffolds in Tissue Engineering
}

\author{
Wan-Ju Li, Rabie M. Shanti, and Rocky S. Tuan
}

3.1

Introduction

Annually, millions of Americans suffer tissue loss or end-stage organ failure at a health care cost exceeding $\$ 400$ billion, representing nearly one-half of all medical related costs in the United States [1]. Approximately 80000 of these patients will await solid organ transplantation, and based on the figures from the United Network for Organ Sharing (UNOS) only 27037 solid organs were transplanted in the United States in 2004. Also, according to the American Association of Tissue Banks (AATB), 1.3 million bone grafts and 94000 soft tissue (e.g., tendon, meniscus) grafts were performed in the United States in 2003. The current standard-ofcare for the replacement of lost or damaged organs and tissues includes transplantation of whole organs from one individual to another (allografts), transplantation of a patient's own tissues from one region of the body to another (autografts), or by the utilization of synthetic materials (alloplasts). Although these therapeutic modalities have had much success in clinical practice, each is associated with significant complications. For instance, allografts are restricted due to limited supply of donor organs and tissues, potential sequelae of chronic immunosuppression, and risk of host immunorejection. Alloplasts or synthetic materials, also have the potential of eliciting an adverse body response, and often fail over time due to wear and fatigue. Therefore, tissue engineering has emerged as a promising alternative for the reconstitution of lost or damaged organs and tissues, circumventing the secondary complications associated with autografts, allografts, and alloplasts.

Three general strategies were devised in the early 1990s for the engineering of new tissue: (1) delivery of cells or cell substitutes, (2) local or systemic delivery of tissue inducing substances, (3) and delivery of scaffolds containing both cells and inductive agents [1]. These approaches typically require some sort of carrier in the form of a biomaterial scaffold to guide the delivery of cells, inductive agents, or a combination of the two to the area of interest. In the same capacity, this biomaterial scaffold can also facilitate the growth and regeneration of new tissue. Figure 3.1 illustrates the general concept of tissue engineering based strategy for therapeutic applications. Briefly, target cells (differentiated/undifferentiated) expanded

Nanotechnologies for the Life Sciences Vol. 9

Tissue, Cell and Organ Engineering. Edited by Challa S. S. R. Kumar

Copyright (c) 2006 WILEY-VCH Verlag GmbH \& Co. KGaA, Weinheim ISBN: 3-527-31389-3 
136 | 3 Electrospinning Technology for Nanofibrous Scaffolds in Tissue Engineering

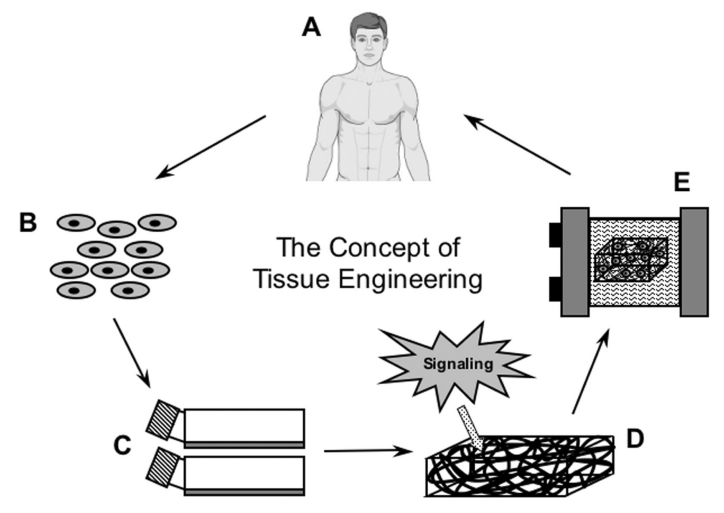

Fig. 3.1. The general concept of tissue engineering. (A) Human tissue or cell donors and recipients. (B) Harvested and isolated cells. (C) Cells expanded in tissue cultures. (D)
Cells cultured in tissue engineered scaffolds and induced by biochemical and mechanical signals. (E) Cellular constructs maintained in bioreactors.

in vitro cultures, usually in cell culture flasks, are cultured in three-dimensional (3D), highly porous biomaterial scaffolds (natural/synthetic) under biologically favored conditions. After a period of culture time, the cellular scaffold receiving chemical and physical growth-needed stimuli turns into a natural tissue-like cellular implant. Furthermore, these biologically functional scaffolds play a critical role in the tissue engineering process, for they provide a 3D structure for cellular functions such as attachment, migration, proliferation, and differentiation and/or serve as vehicles for the delivery of cells to the implant site. The success of this process is determined by the biological and functional similarity of the engineered tissue with native tissue. In summary, whether the biomaterial scaffold serves as a 3D matrix for in vitro culture or functions as a template to recruit surrounding host cells to conduct the repair process, a principal objective of scaffold design for tissue engineering is to create a structure that can simulate the native extracellular matrix (ECM) until cells seeded within the scaffold and/or derived from the host tissue can synthesize a new, natural matrix.

To achieve this goal, a scaffold material must be carefully selected and the scaffold architecture should be properly designed to ensure biocompatibility with the seeded cells. Ideal characteristics for a scaffold include (a) biocompatibility (no cell toxicity before and after degradation of the scaffold material); (b) promotion of cellular activities such as cell adhesion; (c) biodegradability with a controlled rate of degradation that corresponds with tissue growth within the scaffold; (d) a 3D highly porous structure with an interconnected network of microscopic spaces to allow tissue growth and permeation of nutrient medium; (e) favorable mechanical properties; and (f) a highly reproducible and adaptable fabrication process for different shapes or sizes. These characteristics are determined by the material selection and the method of scaffold fabrication [2]. 
Both chemical [3] and physical properties [4] of a scaffold affect cell behavior, ultimately determining the fate of a tissue-engineered scaffold. Progress has been made in the improvement of the chemical biocompatibility of scaffolds through the use of natural polymers [5] or synthetic polymers that incorporate bioactive peptides, such as those containing the arginine-glycine-aspartate (RGD) sequence [6]. Conversely, there has been relatively limited work on the effect of physical properties, such as the 3D architecture of a scaffold, on cell behavior. Cells respond differently to geometrically distinct biomaterial substrates [7]. Specifically, previous studies have demonstrated that cells behave differently when cultured on either two-dimensional (2D) or 3D substrates [8, 9]. For instance, chondrocytes dedifferentiate when cultured on a 2D surface [10], but maintain a stable phenotype when cultured in a 3D agarose hydrogel [11]. Fibroblasts cultured in a 3D environment developed a 3D profile of matrix adhesion, leading to a distinct cytoskeletal organization and induction of specific cell signaling pathways, compared with those cultured on 2D substrates, implying the in vivo relevance of 3D matrix adhesion. Similarly, the advantage of using 3D structures for cell culture has also been shown to have an effect on the maintenance and differentiation of embryonic stem cells [12]. For instance, biomimetic 3D cultures significantly increase hematopoietic differentiation efficacy of embryonic stem cells over their 2D counterparts. The biological relevance of 3D cultures is most likely a consequence of cell-matrix interactions that proceed in a complicated, bidirectional (outside-in and inside-out) manner [13], and are likely to be critical for effective tissue engineering or regeneration. While much is known about the biology of cell-matrix interactions in 2D cultures, relatively little is known about this process in $3 \mathrm{D}$ matrices. To date, two models of 3D environments have been proposed to elucidate the details of this interaction: substrates with a 3D topography, and 3D scaffolds. The former is useful for studying the effects of geometrical variables on cellular activities, but not directly applicable to tissue engineering. Since 3D scaffolds can be fabricated into desired shapes and form interconnected pores to allow tissue ingrowth, they are readily applicable for tissue engineering.

Recent studies have also shown that cells on substrates with varying topography, fabricated using precisely controllable techniques, behave quite differently, suggesting that cells are able to recognize and distinguish geometric properties of substrates, such as shape and/or roughness. For example, Tuan's and Curtis's groups have reported that surface roughness had an effect on osteoblast, endothelial cell, and fibroblast morphology, cytoskeletal properties, and proliferation [14-16]. Other studies have reported that adhesion, proliferation, synthesis of alkaline phosphatase, and deposition of a calcium-containing mineral were all enhanced when osteoblasts were cultured in a nanophase ceramic, compared with micro-grain size ceramics [17, 18]. Increased functions of osteoblasts have also been correlated with a decrease in the diameter of carbon nanofibers [19]. These observations suggest that a scaffold composed of nanometer-scale components is biologically preferred, which is consistent with previous studies reporting that cells favor nanotopographic biomaterial surfaces [18]. As a result, nanometer structural components should be preferred for the fabrication of functional tissue-engineered scaffolds. 
This chapter differs from previously published review articles [20-24] that focus on the electrospinning process and the characterization of electrospun nanofibrous scaffolds by covering in much greater detail the breadth of electrospinning technology and its applications in tissue engineering. Notably, by taking advantage of our research expertise in cell and tissue engineering, we particularly focus on the biological mechanisms and activities enhanced by nanofibers while also reviewing the most up-to-date findings for the development of electrospun nanofibrous scaffolds and the engineering of nanofiber-based tissues. In this chapter, we first emphasize the importance of tissue engineering for clinical applications, introduce electrospun nanofibrous scaffolds by discussing the mechanisms and parameters influencing the properties of electrospun nanofibrous scaffolds, and, finally, review the current development of electrospun nanofibrous scaffolds in tissue engineering applications.

3.2

Nanofibrous Scaffolds

Among nanostructures, nanofibers are more suitable for use as the basic component of a scaffold compared with nanoparticles, due to their continuous structure. The advantage of a scaffold composed of ultrafine, continuous fibers are high porosity, variable pore-size distribution, high surface-to-volume ratio, and, most importantly, morphological similarity to natural ECM [25]. The combination of these features makes nanofibrous structures a favorable scaffold for tissue engineering, as shown by several studies described below.

\subsection{1}

Fabrication Methods for Nanofibrous Scaffolds

Several techniques based on different physical principles have been used to fabricate nanofibrous scaffolds with unique properties.

\subsubsection{Phase Separation}

Phase separation is often utilized as an alternative technique for scaffold fabrication. In most cases, the polymer is dissolved in a solvent at a low temperature, and then the resulting polymer and solvent phases are quenched to create a twophase solid. The solidified solvent is then removed by sublimation, leaving a porous polymeric scaffold behind. In brief, the polymer is dissolved, gelated, and extracted using various solvents. The advantage of using phase separation to fabricate nanofibrous scaffolds is that the shape and size of the pores can be controlled by the addition of porogens [26]. Conversely, a limitation of the foam-like structures produced by phase separation is their compliance and lack of pore interconnectivity.

\subsubsection{Self-assembly}

By definition, self-assembly is the spontaneous organization of molecules into well-defined and macroscopic aggregates [5, 27]. The principle of molecular self- 
assembly is ubiquitous in biological systems, e.g., the aggregation of lipid molecules into micelles in an aqueous environment. In contrast to processes such as electrospinning (see below), which are based on a top-down approach (i.e., materials are broken down into their respective components), self-assembly is based on a bottom-up approach (i.e., materials are assembled molecule by molecule).

On a molecular level, self-assembly is mediated by weak, non-covalent bonds, i.e., ionic bonds, hydrophobic interactions, van der Waals interactions, and watermediated hydrogen bonds [5]. Aside from the balance of these forces, an additional crucial factor of the self-assembly process is complementary shape among the components [27]. To date, much of the work on self-assembly in tissue engineering has focused on the fabrication of 3D nanofibrous structures from amphiphilic peptides. In brief, when placed within an aqueous solution, the hydrophobic and hydrophilic domains within these peptides interact via the aforementioned forces to form distinct strong and fast-recovering hydrogels, with hydrophobic interactions being the principle force that drives the molecules together [28].

Self-assembled 3D nanofibrous scaffolds also closely mimic the porosity and gross structural scale of the natural ECM. Matrices composed of interwoven nanofibers with a diameter of 5-8 $\mathrm{nm}$, and pores of 50-200 $\mathrm{nm}$ diameter $[28,29]$ have been observed by scanning electron microscopy and atomic force microscopy. The biocompatibility of these scaffolds is demonstrated by their ability to support cell proliferation and differentiation [29, 30]. In extended in vitro cultures of bovine chondrocytes within a peptide hydrogel, the chondrocytes encapsulated within the 3D scaffold retained their morphology and developed a cartilaginous extracellular matrix rich in proteoglycans and collagen type II, biochemical markers of a stable chondrocyte phenotype [30].

An advantage of using self-assembly to fabricate nanofibers is that the amino acid residues present may be chemically modified for the addition of bioactive moieties. Furthermore, self-assembly is carried out in aqueous salt solution or physiological media, thus avoiding the use of organic solvents and reducing cytotoxicity.

\subsubsection{Electrospinning}

Electrospinning technology has become popular for the fabrication of tissue engineering scaffolds in recent years (Fig. 3.2). This is a result of the growing interest in nanotechnology and the unique properties and relative ease of fabricating scaffolds using this process. Scaffolds fabricated by electrospinning have a totally different appearance and structure to those made by self-assembly and phase separation. Furthermore, electrospinning technology is exceptionally useful for the fabrication of tissue engineered scaffolds, for not only is the electrospinning equipment economical, but the preparation and fabrication phases are relatively quick compared with phase separation and self-assembly. In addition, the electrospinning system is easy to set up and can be modified to fabricate nanofibrous scaffolds that meet specific requirements for structural or mechanical needs. The advantages of electrospinning technology make it suitable for both small quantity production for laboratory research use and mass production for industrial use. In terms of the properties of scaffolds produced by the different methods, electrospun 


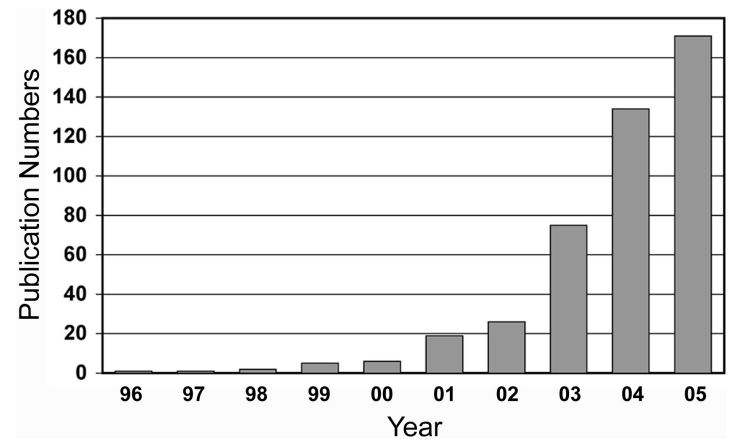

Fig. 3.2. Growth of research using electrospinning technology. The increasing number of scientific publications containing the keyword "electrospinning" indicates the upward trend of electrospinning applications.

nanofibrous scaffolds contain interconnected pores, and possess mechanical and structural stability, that provide superiority over scaffolds fabricated by phase separation and self-assembly. The following sections detail the fabrication technique, properties, and clinical applications of electrospun nanofibrous scaffolds.

\section{2 .2}

\section{The Electrospinning Process}

\subsubsection{History}

Electrospinning was developed based on observations of the "electrospray" phenomenon first described by Lord Rayleigh in 1882 [31]. He discovered that a highly charged droplet was unstable and would break down into smaller droplets when passed through a voltage gradient, a property known as the "Rayleigh instability". Rayleigh proposed that disruption of the droplet surface tension was the result of forces generated through Coulombic repulsion. After this initial study, Zeleny further investigated the electrospraying of aqueous solutions [32, 33], and Dole et al. experimented with electrosprays of dilute polymer solutions [34]. In addition, Vonnegut and Neubauer electrosprayed water and other liquids [35], and Drozin found that electrosprayed droplets resembled a highly dispersed aerosol [36]. These seminal studies laid the foundation for what was to become the electrospinning phenomenon.

Electrospinning is a direct extension of the electrospraying phenomenon, as both processes are based on the same physical and electrical mechanisms. The main difference between the two is that electrospraying produces small droplets, whereas electrospinning produces continuous fibers. In 1934, Formhals electrospun fine fibers from a cellulose acetate solution and was granted a series of U.S. patents on this technology [37]. In 1966, Simons found that more viscous solutions favored the formation of longer fibers [38]. Baumgarten designed an apparatus with an infusion pump to electrospin acrylic fibers, and discovered that the diameter of fibers 


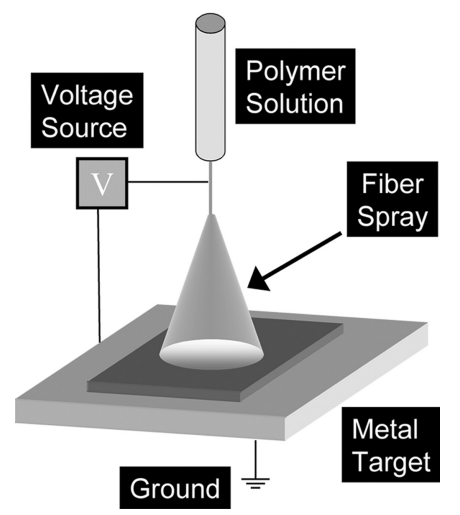

Fig. 3.3. Schema of the electrospinning apparatus (see text for details).

could be controlled by the polymer feed rate from the infusion pump [39]. Finally, Larrondo and Manley electrospun polypropylene and produced polyethylene nanofibers in 1981 [40-42]. The recent, surging interest in nanotechnology has engendered renewed attention to this convenient, economical technology that enables engineers to produce nanofibers for various applications.

\subsubsection{Setup}

The electrospinning apparatus is quite simple, with only three major components: a high voltage power supply, a polymer solution reservoir (e.g., a syringe, with a small diameter needle) with or without a flow control pump, and a metal collecting screen (Fig. 3.3). A high voltage power supply with adjustable control should be able to provide up to $50-\mathrm{kV}$ DC output and, depending on the number of electrospinning jets, multiple outputs that function independently are needed. A reservoir is used to store the polymeric solution and is connected to a power supply to form a charged polymer jet. Either a syringe with a metal needle or a capillary with a metal tip in the polymer solution may be used to charge the polymer solution. Polymer flow can be driven by gravity if the syringe is not horizontally placed. However, to eliminate the experimental variables, a syringe pump is usually used to control the precise flow rate. The fiber collecting screen should be conductive and can be either a stationary plate or a rotary platform or substrate. The plate can produce non-woven fibers, while a rotary platform can produce both nonwoven and aligned fibers.

Currently, there are two standard electrospinning setups, vertical and horizontal. With increasing interest in this technology, several research groups have developed more sophisticated systems that can fabricate more complex nanofibrous structures in a more controlled and efficient manner [43, 44]. For example, motorcontrolled multiple jets and fiber-collecting targets provide a means for fabricating a single nanofibrous scaffold composed of multiple layers, with each layer derived from a different polymer type. Additionally, this technology can be used to fabricate polymer composite scaffolds where the fibers of each layer represent the amal- 
gamation of different polymer types. The multiple jet setup is not only useful for making multi-layer nanofibrous scaffolds, but is also efficient for the production of a large quantity of scaffolding material. Notably, the electrospinning apparatus is usually set up in a chemical fume hood to remove organic vapor. In addition, a closed, non-conductive environment with temperature and humidity control is required to avoid interference from environmental factors, such as air turbulence.

\subsubsection{Mechanism and Working Parameters}

To initiate the electrospinning process, a selected polymer material is dissolved in the appropriate solvent and this solution is loaded into a syringe. A high-voltage electric field is created between the needle and the collecting screen by the use of a power supply and electrodes. When the polymer solution is extruded slowly by a syringe pump and/or gravity, a semispherical polymer solution droplet is formed at the tip of the needle. With increasing voltage, the polymer droplet elongates to form a conical shape known as the Taylor cone [45], causing the surface charge on the polymer droplet to increase with time. Once the surface charge overcomes the surface tension of the polymer droplet, a polymer jet is initiated [46]. The solvent in the polymer jet evaporates during travel to the collecting screen, increasing the surface charge on the jet. This increase in surface charge induces instability in the polymer jet as it passes through the electric field [45]. To compensate for this instability, the polymer jet divides geometrically, first into two jets, and then into many more as the process repeats itself. The formation of nanofibers results from the action of the spinning force provided by the electrostatic force on the continuously splitting polymer droplets. Nanofibers are deposited layer-by-layer on the metal target plate, forming a non-woven nanofibrous mat.

Although the electrospraying/electrospinning technology has been utilized for more than a hundred years, the mechanisms by which nanofibers are formed, much less controlled, have yet to be completely elucidated. Although several studies have been carried out to investigate the mechanism of fiber formation to reproducibly control scaffold design, little theoretical clarity has been achieved. During the electrospinning process, a uniform fibrous structure is created only under optimized operating conditions. Both extrinsic and intrinsic parameters are known to affect the structural morphology of the nanofibers [47]. Specifically, extrinsic parameters, such as environmental humidity and temperature, in addition to intrinsic parameters, including applied voltage, working distance, and conductivity and viscosity of the polymer solution, need to be optimized to produce uniform nanofibers. Generally speaking, the intrinsic parameters are more critical in determining the nanofiber structure. Two major structures are usually found in the nanofibrous mat fabricated by the electrospinning process - a uniform, continuous fibrous structure or a bead-containing fibrous structure. Variation in the relative abundance of these two structures is determined by the relative contributions of the four intrinsic parameters during the electrospinning process.

Polymer Solution Viscosity Polymer solution viscosity, a parameter directly proportional to the concentration of the polymer solution, is the most critical factor in 
controlling the structural morphology of the nanofibrous structure. For fiber formation, polymer viscosity should be in a specific range, depending on the type of polymer and solvent used. Fong et al. used polyethylene oxide (PEO) to study nanofiber formation in different PEO viscosities, and found that a range of viscosity between 1 and 20 poise is suitable for electrospinning uniform nanofibers [48]. Below this range, a bead-containing nanofibrous structure was created. With increasing viscosity, spherical beads became elongated into spindle-shaped ones, and the number of beads in the structure was reduced. Similarly, Liu et al. also reported that a different specific range of viscosity was appropriate for the formation of uniform nanofibers composed of cellulose [49]. In addition, recent studies conducted by Deitzel et al. [50] and Demir et al. [51] have shown that a more viscous polymer solution resulted in larger fibers. Taken together, these studies indicate that there exist polymer-specific, optimal viscosity values for electrospinning.

Applied Charge Density Charge density, as the amount of charge per unit surface area of the polymer droplet, is determined by the applied voltage, the working distance, and the conductivity of the polymer solution. Applied voltage is used to provide the driving force to spin fibers by imparting charge to the polymer droplet. The working distance is defined as the distance between the tip of syringe and the collecting plate and, together with the applied voltage, can influence the structural morphology of nanofibers. Demir et al. suggested that when higher voltages are applied more polymer is ejected to form a larger diameter fiber [51]. Similarly, high voltage conditions also created a rougher fiber structure. Zong et al. proposed an approach to increase charge density on the surface of the droplet by adding salt particles to reduce bead formation [52]. However, their conclusion was that a high charge density produced thinner fibers, a finding not corroborated by Demir et al. [51].

Polymer Solution Conductivity The conductivity of a polymer solution is mainly determined by the polymer type, solvent used, and the availability of ionizable salts. A more conductive polymer solution carries more electric charge during the electrospinning process, with the as-spun fibers generating a stronger repulsive force, which facilitates the formation of bead-free, uniform fibers. Therefore, the general rule for the production of uniform electrospun nanofibers is to electrospin a highly conductive polymeric solution. Since most synthetic biodegradable polymers such as the commonly used poly( $\alpha$-hydroxy esters) do not carry a charge, it is preferred to increase the solvent conductivity. As a result, a dipolar aprotic solvent, $N, N$-dimethylformamide (DMF), which has a high dielectric constant and dipole moment, is added to enhance the solution conductivity [53]. An additional approach entails the use of salts to increase chargeable functional groups in polymeric solutions. The addition of benzyl triethylammonium chloride (BTEAC) [54] or sodium chloride [55], for instance, enhances polymer solution conductivity, in turn reducing fiber size, while producing bead-free fibrous structures. Natural polymers, though, such as collagens, which contain functional groups, usually carry charges when dissolved in solution; however, the polyelectrolyte characteristic 
and hydrogen bonding potential of natural polymers limit the choice of solvents. The use of highly polar fluorinated or acid-based solvents can prevent complicated polymer-polymer and polymer-solvent interactions to smooth the electrospinning process.

\section{2 .3}

Properties of Electrospun Nanofibrous Scaffolds

\subsubsection{Architecture}

An electrospun nanofibrous scaffold has a macro-architecture that is defined by the gross structure of the entire scaffold. The macro-architecture can be machined into a desired dimension and shape, depending on the type of tissue being engineered. However, the micro-architecture is defined by the porous, fibrous structure composed of nanofibers, with the more commonly seen micro-architecture being either a non-woven or an aligned fibrous structure.

Non-woven Nanofibrous Scaffolds Upon ejection from the nozzle of a needle, a polymer jet travels spirally at a high speed in the space between the tip of a needle and the fiber-collecting plate. The jet path is a complicated 3D curve and thus nanofibers are deposited on the target platform in a random manner, resulting in a non-woven structure [56]. Nevertheless, under optimal electrospinning conditions, a homogeneous nanofibrous mat will be formed, with fiber direction in the structure being equally oriented in every direction and polygonal, interconnected pores of various sizes formed between nanofibers. Although deposited fibers lay on and barely contact each other, the interlocking between fibers helps to maintain the micro-architecture of the nanofibrous scaffold. Shape and size of pores are altered only when the structure is subjected to loading.

Aligned Nanofibrous Scaffolds While such randomly oriented scaffolds are useful, a significant number of natural tissues exhibit a preferred fiber alignment. This fiber alignment endows tissues with unique functional material properties that depend on the testing direction and location. For example, in tendon and ligaments, tensile properties are $200-500 \times$ higher along the fiber direction (the direction over which the force is transmitted) than those perpendicular to the fiber direction [3]. In articular cartilage, tensile properties are greatest in the superficial zone of the tissue and highest along the prevailing collagen (split line) direction $[4,5]$. As the goal of tissue engineering is to recapitulate the functional properties of the native tissue, new techniques have been developed for engineering tissue anisotropy.

The strategies in controlling nanofiber alignment generally focus on the as-spun fiber-assembly methods, using either an electrostatic field and/or specially designed collectors such as a rotary target [57] and patterned electrodes [58]. Theron et al. have utilized a rotary disc as a fiber collector to electrically and mechanically align nanofibers [57]. The sharp edge of the disc provides a physically sharp point that serves as an electrode to attract positive-charged nanofibers. The sharp point accumulates charge and generates a strong electrostatic filed. The rotary sharp edge acts like a continuously moving, charged band that forces nanofibers to align 
on a limited strip that winds around the circumference of the disc. In addition, the rotary movement of the disc provides a tangential force, further aligning and stretching nanofibers at the same time. Fiber alignment in this initial study is relatively satisfactory, but the amount of collected aligned nanofiber is limited due to the narrow sharp edge. To increase aligned nanofiber production for tissue engineering applications, it is suggested that a disc is replaced by a drum or a shaft with a large surface area [59]. Doing so will efficiently produce a larger and thicker nanofibrous mat, but without any precise control of fiber alignment. One of the solutions is to increase the rotational speed. Several studies have shown that the nanofiber alignment in a mat is highly dependent on the rotational speed of the drum or shaft [59]. Nanofiber alignment increases with the rotational speed of the collecting surface, and plateaus after reaching an optimal value.

Another practical approach to align nanofibers utilizes a fiber collector consisting of two rectangular conductive electrodes placed on a highly insulating substrate and separated by an air gap [58]. Nanofibers, due to a preferential electrostatic field, are deposited on the electrodes uniaxially across the air gap. The air humidity, in which the electrospinning is carried out, is the major factor affecting the fiber alignment using this approach. Nanofiber alignment increases with the carried charge of as-spun nanofibers and is also enhanced by the reduction of air humidity, since the higher humidity discharges the nanofibers. In addition, fiber orientation is partially determined by the amount of charge left on the deposited nanofibers. The retained charge on deposited nanofibers improves the orientation through electrostatic repulsions between the fibers. Altering the pattern of the electrode array can change the orientation of uniaxial nanofibers and may be useful to fabricate a scaffold with a complicated aligned nanofibrous pattern.

\subsubsection{Porosity}

The internal porous structure of void spaces, or porosity, is a physical component of a biomaterial scaffold that is also dependent on the architectural scale. These pores serve as pathways for mass transport (convection and diffusion), while also providing void space for cells to form new tissues [60]. One technique for measuring the pore diameter distribution, total pore volume, and total pore area of a structure is mercury porosimetry. Utilizing this technology, a $91.63 \%$ porosity was reported for electrospun nanofibrous scaffolds, indicating a highly porous structure [25]. This study also reported a total pore volume of $9.69 \mathrm{~mL} \mathrm{~g}^{-1}$, a total pore area of $23.54 \mathrm{~m}^{2} \mathrm{~g}^{-1}$, and a pore diameter ranging broadly from 2 to $465 \mu \mathrm{m}$ [25]. While some of these pores are too small to influence the migration of cells and facilitate invasion of blood vessels within the scaffold, nutrients and metabolic wastes are still able to pass through these nano-sized pores, thus enhancing engineering of the tissues. In addition, the high porosity of these scaffolds should present a wider path for mass transport, improving cell survival within the scaffold [60].

Although precise control of the pore size in nanofibrous scaffolds is challenging, efforts have been made to fabricate large-pore nanofibrous scaffolds in a more controllable manner. Lee et al. have combined electrospinning technology and salt leaching/gas foaming methods for the fabrication of an electrospun fibrous scaffold with dual-sized pores [61]. In addition to intrinsic pores formed between 
nanofibers, micro-sized pores created by salt particles are distributed in the scaffolds using this modified approach. As porous scaffolds fabricated by the conventional salt-leaching method, pore sizes in electrospun nanofibrous scaffolds are determined by the dimension of the salt particles. The dual-pore, electrospun nanofibrous scaffolds represent an enhanced porous structure for more efficient cell migration and nutrition/waste exchange.

\subsubsection{Mechanical Properties}

As previously discussed, tissue engineering aims to utilize natural and synthetic biomaterials to simulate the 3D environment of the natural ECM. Tissueengineered scaffolds thus also need to match the mechanical properties of the natural environment. The mechanical properties (strength, toughness, modulus, and ductility) of a scaffold are determined by both its structure (macrostructure, microstructure, and nanostructure) and its material properties [60]. Matching the mechanical properties of a scaffold to that of the natural ECM is critically important so that once grafted the progression of tissue healing is not limited by mechanical failure of the scaffold [60]. Furthermore, the mechanical properties of the scaffold can affect cell morphology, proliferation, and differentiation [62].

The process of electrospinning provides ultrafine nanoscale structures that not only geometrically and topologically simulate the natural ECM, but may also mimic the mechanical properties of the natural tissue microenvironment. To accurately investigate the mechanical behavior of nanofibrous scaffolds, it is essential to measure the mechanical properties of individual fibers that make up the scaffold [63]. Such tensile testers must possess the capability of measuring the small load and elongation required for the deformation of these ultrafine fibers, including individual fibers $[63,64]$. In a previous study of the mechanical properties of individual electrospun poly( $\varepsilon$-caprolactone) (PCL) nanofibers, it was shown that mechanical properties varied with fiber diameter, i.e., both tensile strength and yield stress decreased with increased fiber diameter, while an increase in fiber diameter resulted in an increase in strain at break [63]. While in this study it was shown that the strain of break increases with an increase in fiber diameter, yield strain was found to decrease with an increase in fiber diameter, and there was also no apparent correlation between Young's modulus ( $E$ ) and fiber diameter [63]. In summary, the high ductility, and low strength and stiffness of the PCL nanofibers observed in this study depend on the physical properties of the polymer (i.e., low $T_{\mathrm{g}}$ ) and fiber diameter.

\section{3}

Current Development of Electrospun Nanofibrous Scaffolds in Tissue Engineering

\subsection{1}

Evidence Supporting the Use of Nanofibrous Scaffolds in Tissue Engineering

\subsubsection{Nanofibrous Scaffolds Enhance Adsorption of Cell Adhesion Molecules}

Cell adhesion is one of the most important aspects of cell interaction with a biomaterial. It is the first cellular event to take place after cells are seeded onto a bioma- 
terial surface; cell migration, proliferation, and/or differentiation take place only after cells are securely adhered [65]. In native tissues, cells bind via integrins to specific binding sites in the tissue ECM, consisting of specific peptide sequences recognized by the integrins [66]. However, synthetic polymers do not have natural cell binding sites, and cell adhesion to a polymeric scaffold is therefore necessarily mediated by plasma/serum proteins adsorbed onto the polymer surface. Protein adsorption to the polymer surface is affected by the hydrophilicity [67] and the surface energy of the polymer [68]. Cells attach to many ECM proteins, including fibronectin, vitronectin, collagens, and other matrix proteins [69]. Nikolovski et al. showed that vitronectin, compared with fibronectin, was the predominant matrix protein adsorbed from serum-containing medium onto poly(glycolic acid) (PGA) and poly(lactic acid) (PLA) [70]. Woo et al. recently reported that nanofibrous scaffolds for tissue engineering show enhanced adsorption of cell adhesion ECM molecules, which may therefore enhance cell adhesion [71]. The high surfacearea-to-volume ratio of electrospun nanofibrous scaffolds should result in higher adsorption of vitronectin and fibronectin molecules than other scaffolds. In fact, approximately four times as much serum proteins adsorbed to nanofibrous scaffolds compared with scaffolds with solid pore walls. Moreover, fibronectin and vitronectin preferentially adsorbed to the nanofibrous scaffold at a level that was $2-4 \times$ higher than those adsorbed to the solid-walled scaffold [71]. Although the mechanisms by which a nanofibrous scaffold acts as a selective substrate are not yet known, it is clear that the enhanced adsorption of cell adhesion matrix molecules enhances cell adhesion.

\subsubsection{Nanofibrous Scaffolds Induce Favorable Cell-ECM Interaction}

In a native environment, cells are in contact with the ECM and neighboring cells, and cell-matrix interaction act as key regulators of cellular activities [72]. Cells synthesize, assemble, organize, and maintain ECM macromolecules, while the ECM functions to provide structural protection to the resident cells and acts as a messenger regulating cellular activities such as proliferation or differentiation [73]. In postnatal life, the ECM continuously undergoes dynamic turnover to respond to environmental changes caused by biochemical stimulation or mechanical loading. In particular, mechanical signals are transmitted from the environment via the ECM network to cells, which respond to these signals by remodeling the ECM to adapt to the environmental change [74]. Extrapolating from these native interactions, a scaffold that serves as a functional, temporary ECM must involve optimal cell-matrix interactions, as well as cell-cell interactions.

Several reports have demonstrated that nanofibers as scaffolds are more favorable than microfibers, suggesting cell activities can be regulated by the size of the fiber $[75,76]$. One such study evaluated the influence of the structural properties of biomaterial scaffolds on the biological activities of chondrocytes cultured in microfiber- and nanofiber-based scaffolds [75]. The results show that chondrocytes seeded into microfibrous scaffolds display dedifferentiated, fibroblast-like morphology, whereas chondrocytes seeded onto nanofibrous scaffolds maintain a chondrocyte-like morphology (Fig. 3.4). Large, organized stress fibers, commonly found in cells in monolayer culture also appear in cells seeded onto microfibrous 
Acellular Scaffolds

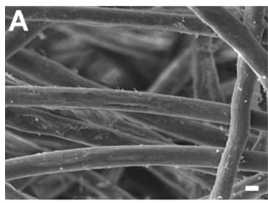

MFS

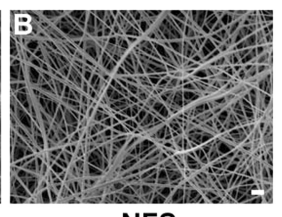

NFS

Fig. 3.4. Ultrastructural morphology of acellular and cellular PLLA microfibrous and nanofibrous scaffolds examined by SEM. (A) A PLLA microfibrous scaffold showing random orientation of microfibers with a diameter ranging from 15 to $20 \mu \mathrm{m}$. (B) A PLLA nanofibrous produced by the electrospinning process, showing random orientation of ultrafine fibers with diameters ranging from

\section{Cellular Scaffolds}

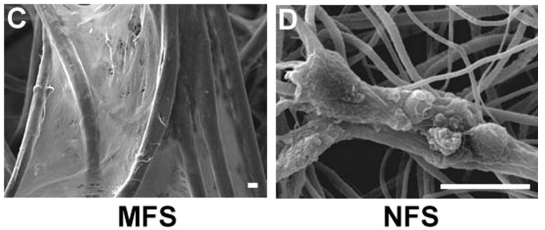

500 to $900 \mathrm{~nm}$, defining a matrix with interconnecting pores. (C) Spread cellular sheets composed of fibroblast-like cells spanned between microfibers in the microfibrous culture after 28 days. (D) Cellular aggregates composed of globular, chondrocytelike cells grew on nanofibers in the nanofibrous culture after 28 days. Bar $=10 \mu \mathrm{m}$.

scaffolds. However, cells seeded in nanofibrous scaffolds do not display a similar cytoskeletal structure. Cell activities such as proliferation and the production of a cartilaginous ECM are enhanced in nanofibrous cultures compared with microfibrous cultures. Overall, these results demonstrate the biological effects of different-sized fibrous biomaterial scaffolds, and suggest that a nanofibrous scaffold is a more effective scaffold for cartilage tissue engineering.

Another study also reported a similar conclusion of nanofibers outperforming microfibers [76], in terms of the biological response of neural stem cells cultured on nanofibrous and microfibrous scaffolds. Unlike the comparison of fibers with a two-order difference in Li's study [75], $300 \mathrm{~nm}$ nanofibers were compared with 1.5 $\mu \mathrm{m}$ microfibers. The results of this study show that a greater percentage of neural stem cells cultured on nanofibrous scaffolds exhibit a neuron-like morphology when compared with microfibrous scaffolds. In addition, the average neurite length of neural stem cells on a nanofibrous scaffold is significantly longer than that of cells on a microfibrous scaffold, suggesting that nanofibers enhance the neurite outgrowth.

One possible explanation for the enhanced performance of nanofibrous scaffolds is that nano-scale fibers, smaller than a cell by two-orders resembling native ECM, create the 3D environment that has spatial advantage in promoting cell-matrix interaction, whereas a scaffold composed of micro-scale fibers with the same order size as a cell does not have such an advantage.

\subsubsection{Nanofibrous Scaffolds Maintain Cell Phenotype}

Chondrocytes isolated from cartilage and cultured in vitro readily undergo dedifferentiation when plated as monolayers, but will redifferentiate and re-express their phenotype maintained in a 3D environment such as collagen gels. Nanofibrous scaffolds have been shown to support the potential of dedifferentiated chondrocytes to redifferentiate in vitro [77]. In this study, fetal bovine chondrocytes were 
seeded onto nanofibrous scaffolds, or as monolayers on standard tissue culture polystyrene (TCPS) as a control substrate. Gene expression analysis shows that chondrocytes seeded on the nanofibrous scaffold and maintained in a serum-free, ITS + supplemented medium continuously maintain their chondrocytic phenotype by expressing cartilage specific ECM genes, including collagen types II and IX, aggrecan, and cartilage oligomeric matrix protein (COMP). Specifically, expression of the collagen type IIB splice variant transcript, which is indicative of the mature chondrocyte phenotype, is up-regulated. Chondrocytes exhibit either a spindle or round shape on the nanofibrous scaffold, in contrast to the flat, well-spread morphology seen in monolayer TCPS cultures. Organized cytoskeletal actin stress fibers are only observed in the cytoplasm of cells cultured on TCPS. Histologically, nanofibrous cultures maintained in supplemented serum-free medium produce more sulfated proteoglycan-rich, cartilaginous matrix than monolayer cultures. In addition to promoting phenotypic differentiation, the nanofibrous scaffold also supports cellular proliferation when the cultures are maintained in serumcontaining medium. These results indicate that the biological activities of chondrocytes are crucially dependent on the architecture of the extracellular scaffolds as well as the composition of the culture medium, and that the nanofibrous scaffold acts as a biologically preferred scaffold/substrate for proliferation and maintenance of the chondrocytic phenotype.

\subsubsection{Nanofibrous Scaffolds Support Differentiation of Stem Cells}

Stem cells, including embryonic and adult stem cells, are promising cell sources for tissue engineering because of their extensive expansion and differentiation capability. Therefore, the biomaterial scaffold used to culture stem cells should be able to support basic stem cell processes, such as proliferation, self-renewal, and differentiation.

Embryonic stem cells (ESCs), different from mesenchymal stem cells (MSCs) isolated from adult tissues, are derived from the inner cell mass of a blastocyst [78]. ESCs have been considered as having the potential of unlimited differentiation, whereas MSCs are more restricted in their differentiation potential. The technique of controlling the fate of ESCs in vitro is complicated and far from mature. One of the requirements for the growth of ESCs is the presence of basement membrane matrix or feeder layers of embryonic fibroblasts. Basement membrane matrix or feeder cell layers provide chemical and physical cues to the ESCs, and maintain their ability to self-renew and differentiate [79]. A nanofibrous structure resembling a basement membrane matrix has been used to culture ESCs to maintain their aforementioned "stemness" properties [80]. The results show that ESCnanofibrous cultures have significantly larger colonies of undifferentiated cells and enhanced proliferation compared with controls cultured on glass coverslips and same-polymer-films, suggesting that the physical cues from the unique geometry of nanofibrous surfaces regulate cellular activities.

Compared with the uncertain future of ESCs in the clinic, owing to ethical and legal issues, adult stem cells provide a promising cell source for stem cell basedtissue engineering. MSCs are undifferentiated, multipotential cells that are capable 
of giving rise to cells characteristic of several tissues, including the connective tissue lineage [81]. Advantages of using MSCs include the fact that MSCs can be isolated from many different adult tissues, such as bone marrow [81], fat [82], umbilical cord blood [83], muscle [84], and synovial membrane [85]. In addition, nanofibrous scaffolds support multi-differentiation of MSCs [86]. In this study, MSCs from bone marrow maintained in nanofibrous scaffolds differentiated along adipogenic, chondrogenic, or osteogenic lineages when induced with specific differentiation media. Gene expression analysis and immunohistochemical detection of lineage-specific marker molecules confirmed the formation of nanofibrous constructs containing cells differentiated into the specified cell types. These results demonstrate the full support of multi-lineage differentiation of MSCs within nanofibrous scaffolds and the feasibility of tissue-engineering multiphasic constructs using a single cell source, which is of particular relevance to the development of multiphasic tissue constructs.

\subsubsection{Nanofibrous Scaffolds Promote in vivo-like 3D Matrix Adhesion and Activate Cell Signaling Pathway}

The observations presented above strongly suggest that nanofibrous scaffolds serve as synthetic ECM networks to provide both chemical and physical stimuli to cells via direct interaction with the cells surface. Unique geometric features of the extracellular matrix, especially ultrafine structure, are generally believed to play a direct and/or indirect role in the regulation of cellular activities. However, studies about cell-nanofiber interactions are new, and the specific mechanisms of how the unique properties of nanofibers enhance cellular activities are largely unknown. From the recently published studies, integrin receptors, cytoskeleton, and signal pathways involving focal adhesion kinase (FAK), Rho, Rac, and Cdc42 GTPases are likely to play a significant role in regulating cells cultured on nanofibrous cultures $[87,88]$. Schindler et al. have demonstrated that nanofibrous cultures promote in vivo-like cell morphology of both fibroblasts and kidney cells [87]. They also showed that both cells cultured on nanofiber surface have less defined, punctate patterns of vinculin and FAK, molecules mediating cell adhesion, at the edge of lamellipodia. In response to the accumulation of cell adhesion molecules at the edge of cells, a notable increase is observed in the formation of actin cytoskeletonrich lamellipodia, membrane ruffles, and cortical actin. Such cellular response is also found in 3D cultures on basement membrane matrix, but not on 2D cultures. Instead, in a flat culture on glass, more vinculin and FAK are accumulated in a streaky pattern, promoting the formation of well-defined actin filaments. The decrease of FAK at the adhesion site, characteristic for cells in tissue, is called "3Dmatrix adhesion". Different from focal adhesion and fibrillar adhesion commonly formed in vitro on flat surfaces, 3D-matrix adhesion takes place in a 3D culture, suggesting that such in vitro cultures may bring the cells closer to in vivo conditions [13]. Thus, nanofibrous cultures should promote the formation of 3D-matrix adhesion and simulate the in vivo microenvironment.

In addition to the formation of 3D-matrix adhesion, nanofibrous cultures also demonstrate different expression profiles of components of cell signaling pathways 
that mediate cell morphology and cytoskeletal organization. These components include members of the family of Rho GTPases, Rho, Rac, and Cdc42, each controlling distinct downstream signal pathways [88]. Cells cultured on a nanofibrous surface extensively activate Rac, which consequently enhances cell proliferation rate and increases the deposition of fibrillar fibronectin. The activated Rac is also found to accumulate at the lamellopodial edge, intracellular vesicles, and dorsal membrane ruffles, often formed in migrating cells and cells cultured in other 3D environment. The activation of Rho and Cdc42 is not as significant as that of Rac. Both GTPases were mildly elevated in the nanofibrous culture than on glass at the early phase of cell attachment. However, the extent of Cdc42 mediating cell polarity decreases along the culture. The nanofibrous scaffolds can dramatically induce the preferential activation of Rac GTPase, suggesting that nanofibrous scaffolds can provide physical as well as spatial cues to activate intracellular signaling pathways that are essential to mimic in vivo-like tissue growth.

3.3 .2

Biomaterials Electrospun into Nanofibrous Scaffolds

Many polymeric biomaterials have been used for tissue engineering applications, including non-biodegradable and biodegradable polymers, with the latter consisting of both natural and synthetic polymers. Non-biodegradable polymers can be utilized to engineer tissues requiring substantial mechanical stability, such as ligament or muscle. However, their long-lasting nature interferes with tissue turnover and remodeling. Therefore, more attention has been devoted to biodegradable polymers in tissue engineering. Polymer biodegradation, by the combined effect of enzymatic and hydrolytic activities, generates space within the scaffold that facilitates cellular processes, such as proliferation and the deposition of newly synthesized ECM. To date, more than one hundred different biodegradable polymers have been successfully electrospun and over thirty of them have been used for various tissue-engineered applications. Table 3.1 summarizes the polymers used in electrospinning, their potential applications, and the evaluation criteria employed in each study.

\subsubsection{Natural Polymeric Nanofibrous Scaffolds}

Because of their more biologically favorable polymeric chemistry towards cell and tissue growth, natural polymers have recently been fabricated into various $3 \mathrm{D}$, tissue engineering scaffolds. Two groups of biocompatible natural polymers electrospun into nanofibers have been used for tissue engineering applications: proteinbased and carbohydrate-based polymers. Protein-based polymers include collagen, gelatin, elastin, silk fibroin, and fibrinogen, and carbohydrate-based polymers include chitin, chitosan, and hyaluronan. Recently, natural polymers have been electrospun into nano-/micro-fibers that are structurally similar to ECM protein fibers.

Collagen Collagen, the most abundant protein family in the body, has been extensively used for in vitro and in vivo tissue engineering. Among the at least 19 differ- 


\section{$152 \mid 3$ Electrospinning Technology for Nanofibrous Scaffolds in Tissue Engineering}

Tab. 3.1. Polymers used in electrospinning, their potential applications, and the evaluation criteria employed.

\begin{tabular}{|c|c|c|c|c|}
\hline Study & Biomaterial & Applications & Characterization & Ref. \\
\hline 1 & PGA & Nonwoven TE scaffold & $\begin{array}{l}\text { SEM, TEM, in vitro rat } \\
\text { cardiac fibroblast culture, in } \\
\text { vivo rat model }\end{array}$ & 168 \\
\hline 2 & PGA & $\begin{array}{l}\text { Nonwoven, aligned TE } \\
\text { scaffold }\end{array}$ & $\begin{array}{l}\text { SEM, mechanical } \\
\text { evaluation }\end{array}$ & 129 \\
\hline 3 & PLGA & Nonwoven TE scaffold & $\begin{array}{l}\text { SEM, porosimetry, } \\
\text { mechanical evaluation, in } \\
\text { vitro human mesenchymal } \\
\text { stem cell and mouse } \\
\text { fibroblast cultures }\end{array}$ & 25 \\
\hline 4 & $\begin{array}{l}\text { PLGA, PLLA, } \\
\text { PDLLA }\end{array}$ & $\begin{array}{l}\text { Biomedical } \\
\text { applications }\end{array}$ & $\begin{array}{l}\text { SEM, degradation analysis, } \\
\text { DSC, WAXD, SAXS }\end{array}$ & 132 \\
\hline 5 & PLGA & $\begin{array}{l}\text { Biomedical } \\
\text { applications }\end{array}$ & $\begin{array}{l}\text { SEM, WAXD, SAXS, } \\
\text { degradation analysis }\end{array}$ & 147 \\
\hline 6 & PLGA & $\begin{array}{l}\text { Wound healing, drug } \\
\text { delivery }\end{array}$ & SEM & 134 \\
\hline 7 & PLGA & Biomaterials & SEM & 135 \\
\hline 8 & PLGA & $\begin{array}{l}\text { Nonwoven TE } \\
\text { scaffold, peripheral } \\
\text { nerve }\end{array}$ & SEM, in vivo rat model & 169 \\
\hline 9 & PLGA/PEG-PLA & $\begin{array}{l}\text { Prevention of } \\
\text { postsurgical } \\
\text { abdominal } \\
\text { adhesions }\end{array}$ & SEM, in vivo rat model & 154 \\
\hline 10 & PCL & Nonwoven TE scaffold & $\begin{array}{l}\text { SEM, WAXD, mechanical } \\
\text { evaluation }\end{array}$ & 53 \\
\hline 11 & PCL & $\begin{array}{l}\text { Nonwoven TE scaffold } \\
\text { bone }\end{array}$ & $\begin{array}{l}\text { SEM, in vitro rat } \\
\text { mesenchymal stem cell } \\
\text { culture }\end{array}$ & 137 \\
\hline 12 & PCL & $\begin{array}{l}\text { Nonwoven TE scaffold } \\
\text { bone }\end{array}$ & SEM, in vivo rat model & 138 \\
\hline 13 & PCL & $\begin{array}{l}\text { Nonwoven TE scaffold } \\
\text { cardiac tissue }\end{array}$ & $\begin{array}{l}\text { SEM, in vitro rat } \\
\text { cardiomyocyte culture }\end{array}$ & 139 \\
\hline 14 & PCL & $\begin{array}{l}\text { Nonwoven TE scaffold } \\
\text { cartilage }\end{array}$ & $\begin{array}{l}\text { SEM, in vitro human } \\
\text { mesenchymal stem cell } \\
\text { culture }\end{array}$ & 140 \\
\hline 15 & PCL & $\begin{array}{l}\text { Nonwoven TE scaffold } \\
\text { cartilage }\end{array}$ & $\begin{array}{l}\text { SEM, in vitro bovine } \\
\text { chondrocyte culture }\end{array}$ & 77 \\
\hline
\end{tabular}


Tab. 3.1 (continued)

\begin{tabular}{|c|c|c|c|c|}
\hline Study & Biomaterial & Applications & Characterization & Ref. \\
\hline 16 & PCL & Nonwoven TE scaffold & $\begin{array}{l}\text { SEM, WAXD, mechanical } \\
\text { evaluation, in vitro MCF-7 } \\
\text { mammary carcinoma cell } \\
\text { culture }\end{array}$ & 141 \\
\hline 17 & PCL & Nonwoven TE scaffold & $\begin{array}{l}\text { SEM, in vitro human } \\
\text { coronary smooth muscle } \\
\text { cell culture }\end{array}$ & 142 \\
\hline 18 & PCL & $\begin{array}{l}\text { Nonwoven, aligned TE } \\
\text { scaffold }\end{array}$ & $\begin{array}{l}\text { SEM, surface contact angle } \\
\text { test, in vitro human } \\
\text { endothelial cell culture }\end{array}$ & 99 \\
\hline 19 & PCL & Nonwoven TE scaffold & $\begin{array}{l}\text { SEM, TEM, in vitro human } \\
\text { dermal fibroblast culture }\end{array}$ & 143 \\
\hline 20 & PCL & $\begin{array}{l}\text { Nonwoven TE scaffold } \\
\text { skin }\end{array}$ & $\begin{array}{l}\text { SEM, in vitro human } \\
\text { dermal fibroblast culture }\end{array}$ & 144 \\
\hline 21 & PCL, PLA & $\begin{array}{l}\text { Nonwoven TE scaffold } \\
\text { blood vessel }\end{array}$ & $\begin{array}{l}\text { SEM, mechanical } \\
\text { evaluation, in vitro mouse } \\
\text { fibroblast and human } \\
\text { venous saphenous } \\
\text { myofibroblast cultures }\end{array}$ & 145 \\
\hline 22 & $\begin{array}{l}\text { PCL, PCL/ } \\
\mathrm{CaCO}_{3}\end{array}$ & $\begin{array}{l}\text { Nonwoven TE scaffold } \\
\text { bone }\end{array}$ & $\begin{array}{l}\text { SEM, surface contact angle } \\
\text { test, mechanical evaluation, } \\
\text { in vitro human osteoblast } \\
\text { culture }\end{array}$ & 146 \\
\hline 23 & $\begin{array}{l}\text { PCL, PCL/ } \\
\text { gelatin, gelatin }\end{array}$ & Nonwoven TE scaffold & $\begin{array}{l}\text { SEM, surface contact angle } \\
\text { test, mechanical evaluation, } \\
\text { in vitro bone marrow } \\
\text { stromal cell culture }\end{array}$ & 170 \\
\hline 24 & PLLA & $3 \mathrm{D}$ cell substrate & $\begin{array}{l}\text { SEM, in vitro human } \\
\text { chondrocyte culture }\end{array}$ & 171 \\
\hline 25 & PLLA & Nonwoven TE scaffold & $\begin{array}{l}\text { SEM, in vitro mouse } \\
\text { cerebellum stem cell } \\
\text { culture }\end{array}$ & 172 \\
\hline 26 & PLLA & Surface coating & $\begin{array}{l}\text { SEM, AFM, in vitro } \\
\text { endothelial cell culture }\end{array}$ & 173 \\
\hline 27 & PLLA & $\begin{array}{l}\text { Nonwoven, aligned TE } \\
\text { scaffold nerve }\end{array}$ & $\begin{array}{l}\text { SEM, in vitro mouse } \\
\text { cerebellum stem cell } \\
\text { culture }\end{array}$ & 76 \\
\hline
\end{tabular}


$154 \mid 3$ Electrospinning Technology for Nanofibrous Scaffolds in Tissue Engineering

Tab. 3.1 (continued)

\begin{tabular}{|c|c|c|c|c|}
\hline Study & Biomaterial & Applications & Characterization & Ref. \\
\hline 28 & $\begin{array}{l}\text { PLGA/PEG- } \\
\text { PDLLA, PLLA/ } \\
\text { PLGA, PLLA }\end{array}$ & $\begin{array}{l}\text { Nonwoven, aligned TE } \\
\text { scaffold heart }\end{array}$ & $\begin{array}{l}\text { SEM, surface contact angle } \\
\text { test, degradation analysis, } \\
\text { in vitro rat cardiomyocyte } \\
\text { culture }\end{array}$ & 174 \\
\hline 29 & $\begin{array}{l}\text { PDLLA-PEG- } \\
\text { PDLLA, PDLLA, } \\
\text { PLGA }\end{array}$ & $\begin{array}{l}\text { Biomedical } \\
\text { applications }\end{array}$ & $\begin{array}{l}\text { SEM, degradation analysis, } \\
\text { surface contact angle test, } \\
\text { in vitro mouse calvaria } \\
\text { osteoblast culture }\end{array}$ & 175 \\
\hline 30 & $\begin{array}{l}\text { PLLA, PDLLA, } \\
\text { PEG-PLLA, } \\
\text { PEG-PDLLA }\end{array}$ & Nonwoven TE scaffold & $\begin{array}{l}\text { SEM, surface contact angle } \\
\text { test, in vitro mouse calvaria- } \\
\text { derived osteoprogenitor } \\
\text { culture }\end{array}$ & 176 \\
\hline 31 & PLLA/MMT & Nonwoven TE scaffold & SEM & 177 \\
\hline 32 & P(LLA-CL) & $\begin{array}{l}\text { Aligned TE scaffold } \\
\text { blood vessel }\end{array}$ & $\begin{array}{l}\text { SEM, in vitro human } \\
\text { coronary artery smooth } \\
\text { muscle cell culture }\end{array}$ & 160 \\
\hline 33 & P(LLA-CL) & Nonwoven TE scaffold & $\begin{array}{l}\text { SEM, DSC, XRD, in vitro } \\
\text { human coronary artery } \\
\text { endothelial and smooth } \\
\text { muscle cell cultures }\end{array}$ & 178 \\
\hline 34 & P(LLA-CL) & Nonwoven TE scaffold & $\begin{array}{l}\text { SEM, mechanical } \\
\text { evaluation, in vitro human } \\
\text { coronary muscle and } \\
\text { endothelial cell cultures }\end{array}$ & 179 \\
\hline 35 & P(LLA-CL) & $\begin{array}{l}\text { Nonwoven TE scaffold } \\
\text { blood vessel }\end{array}$ & $\begin{array}{l}\text { SEM, flow press analysis, } \\
\text { mechanical evaluation }\end{array}$ & 180 \\
\hline 36 & P(LLA-CL) & $\begin{array}{l}\text { Nonwoven TE scaffold } \\
\text { blood vessel }\end{array}$ & $\begin{array}{l}\text { SEM, }{ }^{1} \mathrm{H} \text { NMR, } \\
\text { porosimetry, mechanical } \\
\text { evaluation, in vitro human } \\
\text { umbilical vein endothelial } \\
\text { cell culture }\end{array}$ & 181 \\
\hline 37 & P(LLA-CL) & $\begin{array}{l}\text { Nonwoven TE scaffold } \\
\text { blood vessel }\end{array}$ & $\begin{array}{l}\text { SEM, porosimetry, } \\
\text { mechanical evaluation, in } \\
\text { vitro human coronary artery } \\
\text { endothelial cell culture }\end{array}$ & 157 \\
\hline 38 & $\mathrm{P}($ CL-EEP $)$ & $\begin{array}{l}\text { Nonwoven TE scaffold } \\
\text { liver }\end{array}$ & $\begin{array}{l}\text { SEM, in vitro rat hepatocyte } \\
\text { culture }\end{array}$ & 182 \\
\hline 39 & $\mathrm{PNmPh}$ & $\begin{array}{l}\text { Biomedical } \\
\text { applications }\end{array}$ & $\begin{array}{l}\text { SEM, NMR, viscosity } \\
\text { analysis, DSC, in vitro } \\
\text { mouse calvarial cell culture }\end{array}$ & 183 \\
\hline
\end{tabular}


Tab. 3.1 (continued)

\begin{tabular}{|c|c|c|c|c|}
\hline Study & Biomaterial & Applications & Characterization & Ref. \\
\hline 40 & PHBV & Nonwoven TE scaffold & $\begin{array}{l}\text { SEM, in vitro chondrocyte } \\
\text { culture }\end{array}$ & 184 \\
\hline 41 & PHBV & Nonwoven TE scaffold & $\begin{array}{l}\text { SEM, viscosity analysis, } \\
\text { degradation analysis }\end{array}$ & 54 \\
\hline 42 & PHBV & Nonwoven TE scaffold & $\begin{array}{l}\text { SEM, surface contact angle } \\
\text { test, in vitro monkey kidney } \\
\text { cell culture }\end{array}$ & 185 \\
\hline 43 & PEU & $\begin{array}{l}\text { Nonwoven TE scaffold } \\
\text { skeletal muscle }\end{array}$ & $\begin{array}{l}\text { SEM, degradation analysis, } \\
\text { mechanical evaluation, in } \\
\text { vitro murine myoblast, rat } \\
\text { myoblast, and human } \\
\text { satellite cell cultures }\end{array}$ & 161 \\
\hline 44 & PEUU & $\begin{array}{l}\text { Nonwoven TE scaffold } \\
\text { cardiovascular tissues }\end{array}$ & $\begin{array}{l}\text { SEM, mechanical } \\
\text { evaluation, in vitro rat } \\
\text { vascular smooth muscle } \\
\text { cell culture }\end{array}$ & 44 \\
\hline 45 & PEUU/Col I & $\begin{array}{l}\text { Nonwoven TE scaffold } \\
\text { soft tissue }\end{array}$ & $\begin{array}{l}\text { SEM, circular dichroism } \\
\text { spectroscopy, mechanical } \\
\text { evaluation, in vitro vascular } \\
\text { smooth muscle cell culture }\end{array}$ & 186 \\
\hline 46 & $\begin{array}{l}\text { PPDO-PLLA-b- } \\
\text { PEG }\end{array}$ & Nonwoven TE scaffold & $\begin{array}{l}\text { SEM, porosimetry, } \\
\text { mechanical evaluation, } \\
\text { degradation analysis, in } \\
\text { vitro fibroblast cell culture }\end{array}$ & 187 \\
\hline 47 & PU & $\begin{array}{l}\text { Nonwoven, aligned TE } \\
\text { scaffold ligament }\end{array}$ & $\begin{array}{l}\text { SEM, mechanical } \\
\text { evaluation, in vitro human } \\
\text { ligament fibroblast culture }\end{array}$ & 164 \\
\hline 48 & PU & $\begin{array}{l}\text { Nonwoven tissue } \\
\text { template wound } \\
\text { healing }\end{array}$ & $\begin{array}{l}\text { SEM, in vivo guinea pig } \\
\text { model }\end{array}$ & 188 \\
\hline 49 & PU & $\begin{array}{l}\text { Nonwoven TE scaffold } \\
\text { blood vessel }\end{array}$ & $\begin{array}{l}\text { SEM, flow pressure } \\
\text { analysis, mechanical } \\
\text { evaluation }\end{array}$ & 189 \\
\hline 50 & PU & Biomaterial & $\begin{array}{l}\text { SEM, porosimetry, } \\
\text { mechanical evaluation }\end{array}$ & 190 \\
\hline 51 & PET & $\begin{array}{l}\text { Nonwoven TE scaffold } \\
\text { blood vessel }\end{array}$ & $\begin{array}{l}\text { SEM, XPS, surface contact } \\
\text { angle test, in vitro human } \\
\text { coronary artery endothelial } \\
\text { cell culture }\end{array}$ & 191 \\
\hline
\end{tabular}


$156 \mid 3$ Electrospinning Technology for Nanofibrous Scaffolds in Tissue Engineering

Tab. 3.1 (continued)

\begin{tabular}{|c|c|c|c|c|}
\hline Study & Biomaterial & Applications & Characterization & Ref. \\
\hline 52 & PEVA & Nonwoven TE scaffold & $\begin{array}{l}\text { SEM, in vitro human aortic } \\
\text { smooth muscle cell and } \\
\text { dermal fibroblast cultures }\end{array}$ & 148 \\
\hline 53 & PS & $\begin{array}{l}\text { Nonwoven TE scaffold } \\
\text { skin }\end{array}$ & $\begin{array}{l}\text { SEM, in vitro human } \\
\text { fibroblast, keratinocyte, and } \\
\text { endothelial single or co- } \\
\text { cultures }\end{array}$ & 192 \\
\hline 54 & PDS & $\begin{array}{l}\text { Nonwoven, aligned TE } \\
\text { scaffold biomedical } \\
\text { applications }\end{array}$ & $\begin{array}{l}\text { SEM, viscosity analysis, } \\
\text { mechanical evaluation }\end{array}$ & 193 \\
\hline 55 & $\begin{array}{l}\text { PEG-LMWH/ } \\
\text { PLGA, PEG- } \\
\text { LMWH/PEO }\end{array}$ & Biomaterial & $\begin{array}{l}\text { SEM, EDX, multiphoton } \\
\text { microscopy }\end{array}$ & 194 \\
\hline 56 & $\mathrm{PVA} / \mathrm{CA}$ & Biomaterials & $\begin{array}{l}\text { SEM, FTIR, WAXD, } \\
\text { mechanical evaluation }\end{array}$ & 156 \\
\hline 57 & Fibrinogen & $\begin{array}{l}\text { Nonwoven TE scaffold } \\
\text { wound healing }\end{array}$ & $\begin{array}{l}\text { SEM, TEM, mechanical } \\
\text { evaluation }\end{array}$ & 115 \\
\hline 58 & Col I/PEO & $\begin{array}{l}\text { Nonwoven TE scaffold } \\
\text { wound healing }\end{array}$ & $\begin{array}{l}\text { SEM, TEM, }{ }^{1} \mathrm{H} \text { NMR } \\
\text { spectroscopy, mechanical } \\
\text { evaluation }\end{array}$ & 152 \\
\hline 59 & Col I, Col III & Nonwoven TE scaffold & $\begin{array}{l}\text { SEM, TEM, mechanical } \\
\text { evaluation, in vitro aortic } \\
\text { smooth muscle cell culture }\end{array}$ & 91 \\
\hline 60 & Col I & $\begin{array}{l}\text { Nonwoven TE scaffold } \\
\text { wound healing }\end{array}$ & $\begin{array}{l}\text { SEM, degradation, } \\
\text { porosimetry, mechanical } \\
\text { evaluation, in vitro human } \\
\text { oral and epithermal } \\
\text { keratinocyte cultures, in } \\
\text { vivo rat model }\end{array}$ & 92 \\
\hline 61 & $\begin{array}{l}\text { Col I/elastin/ } \\
\text { PLGA }\end{array}$ & $\begin{array}{l}\text { Nonwoven TE scaffold } \\
\text { blood vessel }\end{array}$ & $\begin{array}{l}\text { SEM, mechanical } \\
\text { evaluation, in vitro bovine } \\
\text { endothelial and smooth } \\
\text { muscle cell cultures }\end{array}$ & 102 \\
\hline 62 & $\begin{array}{l}\text { Col I/elastin/ } \\
\text { PEO, Col I/PEO, } \\
\text { elastin/PEO }\end{array}$ & Nonwoven TE scaffold & $\begin{array}{l}\text { SEM, surface tension } \\
\text { analysis, viscosity analysis, } \\
\text { DSC, amino group } \\
\text { detection }\end{array}$ & 103 \\
\hline 63 & $\begin{array}{l}\text { Col I, gelatin, } \\
\text { PGA, PGA/PLA, } \\
\text { PLA }\end{array}$ & Nonwoven TE scaffold & SEM, in vivo rat model & 93 \\
\hline
\end{tabular}


Tab. 3.1 (continued)

\begin{tabular}{|c|c|c|c|c|}
\hline Study & Biomaterial & Applications & Characterization & Ref. \\
\hline 64 & $\begin{array}{l}\text { Col I, Col III, } \\
\text { elastin }\end{array}$ & $\begin{array}{l}\text { Nonwoven TE scaffold } \\
\text { blood vessel }\end{array}$ & $\begin{array}{l}\text { SEM, in vitro human } \\
\text { umbilical vein endothelial } \\
\text { cell, aortic smooth muscle } \\
\text { cell, and dermal fibroblast } \\
\text { cultures }\end{array}$ & 94 \\
\hline 65 & $\begin{array}{l}\text { Col I, gelatin, } \\
\text { PU, PEO }\end{array}$ & Nonwoven TE scaffold & $\begin{array}{l}\text { SEM, laser scanning } \\
\text { confocal microscopy, } \\
\text { mechanical evaluation }\end{array}$ & 43 \\
\hline 66 & $\begin{array}{l}\text { Col I, gelatin, } \\
\text { elastin, } \\
\text { tropoelastin }\end{array}$ & Nonwoven TE scaffold & $\begin{array}{l}\text { SEM, AFM, mechanical } \\
\text { evaluation, in vitro human } \\
\text { embryonic palatal } \\
\text { mesenchymal cell culture }\end{array}$ & 95 \\
\hline 67 & Col II & Nonwoven TE scaffold & SEM & 96 \\
\hline 68 & Col II & $\begin{array}{l}\text { Nonwoven TE scaffold } \\
\text { cartilage }\end{array}$ & $\begin{array}{l}\text { SEM, mechanical } \\
\text { evaluation, in vitro adult } \\
\text { human articular } \\
\text { chondrocyte culture }\end{array}$ & 97 \\
\hline 69 & Elastin-mimetic & Nonwoven TE scaffold & SEM & 104 \\
\hline 70 & $\begin{array}{l}\text { Silk fibroin, } \\
\text { silk/PEO }\end{array}$ & Nonwoven TE scaffold & SEM, FTIR, XPS & 105 \\
\hline 71 & Silk, silk/PEO & Nonwoven TE scaffold & $\begin{array}{l}\text { SEM, XPS, DSC, } \\
\text { mechanical evaluation, in } \\
\text { vitro human bone marrow } \\
\text { stromal cell culture }\end{array}$ & 106 \\
\hline 72 & Silk & $\begin{array}{l}\text { Biomedical } \\
\text { applications }\end{array}$ & $\begin{array}{l}\mathrm{SEM},{ }^{13} \mathrm{C} \mathrm{CP} / \mathrm{MAS} \text { NMR, } \\
\text { mechanical evaluation }\end{array}$ & 107 \\
\hline 73 & Silk & $\begin{array}{l}\text { Biomedical } \\
\text { applications }\end{array}$ & SEM, TEM, WAXD & 108 \\
\hline 74 & Silk fibroin & $\begin{array}{l}\text { Nonwoven TE scaffold } \\
\text { wound healing }\end{array}$ & $\begin{array}{l}\text { SEM, porosimetry, in vitro } \\
\text { human keratinocyte and } \\
\text { fibroblast cultures }\end{array}$ & 109 \\
\hline 75 & Silk fibroin & $\begin{array}{l}\text { Nonwoven, woven TE } \\
\text { scaffold wound } \\
\text { healing }\end{array}$ & $\begin{array}{l}\text { SEM, ATR-IR, }{ }^{13} \mathrm{C} \mathrm{CP} / \mathrm{MAS} \\
\mathrm{NMR}, \mathrm{WAXD}, \mathrm{NMR} \text {, in } \\
\text { vitro human keratinocyte } \\
\text { culture }\end{array}$ & 110 \\
\hline 76 & Silk/chitosan & $\begin{array}{l}\text { Nonwoven TE scaffold } \\
\text { wound dressings }\end{array}$ & $\begin{array}{l}\text { SEM, viscosity analysis, } \\
\text { conductivity }\end{array}$ & 111 \\
\hline 77 & Chitin, chitosan & Wound dressings & $\begin{array}{l}\text { SEM, }{ }^{1} \text { H NMR, FTIR, } \\
\text { WAXD, DSC, TGA }\end{array}$ & 120 \\
\hline
\end{tabular}


158 Electrospinning Technology for Nanofibrous Scaffolds in Tissue Engineering

Tab. 3.1 (continued)

\begin{tabular}{|c|c|c|c|c|}
\hline Study & Biomaterial & Applications & Characterization & Ref. \\
\hline 78 & Chitosan & $\begin{array}{l}\text { Nonwoven, aligned TE } \\
\text { scaffold cartilage }\end{array}$ & $\begin{array}{l}\text { SEM, mechanical } \\
\text { evaluation, degradation, in } \\
\text { vitro canine chondrocyte } \\
\text { culture }\end{array}$ & 121 \\
\hline 79 & Chitosan & Nonwoven biomaterial & SEM & 122 \\
\hline 80 & Chitosan/PEO & $\begin{array}{l}\text { Nonwoven TE } \\
\text { scaffold, drug delivery, } \\
\text { wound healing }\end{array}$ & SEM, XPS, FTIR, DSC & 153 \\
\hline 81 & Chitosan/PEO & $\begin{array}{l}\text { Nonwoven, aligned TE } \\
\text { scaffold }\end{array}$ & $\begin{array}{l}\text { SEM, viscosity analysis, in } \\
\text { vitro human chondrocyte } \\
\text { and osteoblast cultures }\end{array}$ & 195 \\
\hline 82 & Chitin/PLGA & Nonwoven TE scaffold & $\begin{array}{l}\text { SEM, in vitro human oral } \\
\text { keratinocyte and epidermal } \\
\text { keratinocyte cultures }\end{array}$ & 158 \\
\hline 83 & Gelatin & $\begin{array}{l}\text { Nonwoven TE scaffold } \\
\text { wound healing }\end{array}$ & $\begin{array}{l}\text { SEM, mechanical } \\
\text { evaluation }\end{array}$ & 101 \\
\hline 84 & $\begin{array}{l}\text { Oxidized } \\
\text { cellulose }\end{array}$ & Adhesion barriers & SEM, FTIR, WAXD, TGA & 196 \\
\hline 85 & $\mathrm{HA}$ & Medical implant & SEM & 127 \\
\hline
\end{tabular}

PGA = poly(glycolide), PLGA = poly(lactide-co-glycolide), PLLA = poly( I-lactide),

PDLLA $=$ poly (D,L-lactide), PEG = poly(ethylene glycol $),$ PCL = poly $(\varepsilon$-caprolactone $)$,

$\mathrm{MMT}=$ montmorillonite, $\mathrm{P}($ LLA-CL $)=$ poly $(\mathrm{L}$-lactide-co-e-caprolactone $), \mathrm{P}(\mathrm{CL}-$

$\mathrm{EEP})=\operatorname{poly}(\varepsilon$-caprolactone-co-ethyl ethylene phosphate $), \mathrm{PNmPh}=\operatorname{poly}[\mathrm{bis}(p$ methylphenoxy)phosphazene], PHBV = poly(3-hydroxybutyrate-co-3-

hydroxyvalerate), $\mathrm{PEU}=$ polyetherurethane, $\mathrm{PEUU}=$ poly(ester urethane $)$ urea, $\mathrm{PPDO}=\operatorname{poly}(p$-dioxanone $), \mathrm{PU}=$ polyurethane, $\mathrm{PET}=$ polyethylene terephthalate, PEVA $=$ poly (ethylene-co-vinyl alcohol $), \mathrm{PS}=$ polystyrene, $\mathrm{PDS}=$ polydioxanone, LMWH $=$ low molecular weight heparin, $\mathrm{PVA}=$ poly(vinyl alcohol), $\mathrm{CA}=$ cellulose acetate, $\mathrm{PEO}=$ poly(ethylene oxide), $\mathrm{Col} \mathrm{I}=$ collagen type I, Col II = collagen type $\mathrm{II}$, Col III = collagen type III, HA = hyaluronic acid, TE = tissue engineering, $\mathrm{SEM}=$ scanning electron microscopy, TEM = transmission electron microscopy, $\mathrm{DSC}=$ differential scanning calorimetry, WAXD $=$ wide-angle X-ray diffraction, $\mathrm{SAXS}=$ small angle $\mathrm{X}$-ray scattering, $\mathrm{AFM}=$ atomic force microscopy, $\mathrm{XRD}=$ $\mathrm{X}$-ray diffractometry, NMR $=$ nuclear magnetic resonance, $\mathrm{XPS}=\mathrm{X}$-ray photoelectron spectroscopy, EDX = energy dispersive X-ray, ATR-IR = attenuated total reflectance infrared spectroscopy, FTIR = Fourier-transform infrared spectroscopy, TGA $=$ thermogravimetric analysis. 
ent collagen types, collagen type I is the major collagen in connective tissues and collagen type II is exclusively abundant in hyaline cartilage. Both collagen types I and II have been fabricated into different scaffolds, mostly in a gel-format, to repair tissue defects in vivo $[89,90]$. Collagen electrospinning provides an in vitro method to create a preformed, nanofibrous collagen scaffold that closely mimics the native collagen network [43, 91-97]. For instance, Matthews et al. have demonstrated that, under optimal working parameters, electrospinning can be adapted to fabricate collagen types I and III nanofibers [91]. Electrospun fibers of skin-derived collagen type I and placenta-derived collagen type III were shown to be more uniform than fibers of placenta-derived collagen type I, suggesting that the diameter of electrospun collagen fibers varies with tissue origin and collagen type. Interestingly, electrospun collagen type I nanofibers exhibit the periodic banding pattern typical of native collagen, further demonstrating the potential of electrospinning in the fabrication of natural collagen fibers. Collagen type II has also been successfully electrospun. Being a major fibrous component of the ECM in hyaline cartilage, collagen type II networks are extremely important in cartilage regeneration. Electrospinning collagen type II is a promising approach to reconstruct collagen networks in vitro. However, one of drawbacks on using electrospun collagen scaffolds is their rapid degradation in culture. A study by Shields et al., comparing the properties of crosslinked and non-crosslinked scaffolds using glutaraldehyde as the crosslinking agent, found crosslinking to increase the diameter of collagen fibers as well as the thickness of the scaffold [97]. This study also demonstrated that electrospun collagen type II fibers are relatively larger but mechanically weaker than native collagen fibers. Although not fully recapitulating the properties of the native collagen type II network formed in cartilage, electrospun collagen type II scaffolds still hold promise in cartilage tissue engineering due to their ability to closely mimic the natural ECM.

Gelatin Gelatin is the denatured form of collagen type I, a natural protein-based polymer that is extensively used in the biomedical and food industries. Unlike the triple-helical collagen from which is derived, the denatured protein chain of gelatin is readily soluble in water at room temperature. Tissue engineered scaffolds made of gelatin usually require treatment with a crosslinking agent to maintain their structural integrity in a physiological environment, due to their ready dissociation in physiological solution. It is also common for gelatin to be grafted or blended with other polymers in the preparation of tissue engineering scaffolds [98, 99]. Like most protein polymers, gelatin contains amine and carboxylic groups, which are easily ionized in water to carry charge. This polyelectrolyte property of gelatin, coupled with its strong hydrogen bonding makes electrospinning of a gelatin aqueous solution quite challenging $[43,93,95,100]$. In a study by Huang et al., highly polar fluorinated solvents were used to prepare a gelatin solution with an optimal concentration for electrospinning [101]. This study also showed that the mechanical performance of a gelatin mat is determined by fiber morphology, which is dependent on polymer concentration. For instance, an increase the average diameter of gelatin fibers from $100 \mathrm{~nm}$ to $1.9 \mu \mathrm{m}$ was achieved by increasing polymer con- 
centration, with smaller uniform fibers being mechanically stronger than larger uniform fibers.

Elastin Elastin is a highly water-insoluble protein that functions as a "perfect coil" to provide elasticity to tissues that need to be stretched and recoiled. However, it is rare for elastin to be used alone as a material to fabricate tissue engineering scaffolds $[94,95]$. Elastin-containing tissues generally also contain collagen fibers [102, 103]. For instance, tissues such as skin, lung, and blood vessels are composed of collagen fibers for tensile properties and elastin fibers for elastic properties. Nagapudi et al. used a genetic engineering approach to synthesize recombinant elastinmimetic proteins, and which were electrospun into nanofibers with different properties [104]. Elastin-mimetic proteins dissolved in a highly polar fluorinated solvent were electrospun into smaller fibers, compared with those dissolved in aqueous solution, suggesting that different fibrous morphologies of natural polymers could result from the use of different solvents, such as highly polar fluorinated solvent and water.

Silk Fibroin Besides collagen, silk fibroin is another protein-based, natural polymer most commonly used for electrospinning. With a long history of textile use, beginning with the ancient Chinese, silk has recently been applied for the fabrication of tissue engineering scaffolds [105-111]. One of the most significant properties of silk is its excellent mechanical properties. Natural silk is produced by spiders or silkworms, with different composition and properties among species. A study by Ohgo et al. comparing three electrospun silk fibroin nanofibers suggested that silk fibroins from two different silkworms and genetically engineered silk-like protein each required individual optimal polymer concentration for electrospinning [107]. In addition, the engineered silk-like protein nanofibers were reported to be smaller than the natural silk fibroin nanofibers, and the mechanical strength of silk fibroin nanofibrous mats was also dependent on silk fibroin type.

Fibrinogen Purified from blood plasma, fibrinogen is a globular protein that plays a critical role in wound healing. In the presence of thrombin, fibrinogen gives rise to fibrin which forms fibrous clots that have found use as a clinical fixative, due to its natural role in wound healing. Fibrin has recently attracted scientific attention for use as a scaffold to deliver cells [112,113] or growth factors [114] for tissue engineering. Due to the high surface area to volume ratio available for clot formation, electrospun nanofibrous fibrinogen mats are highly suitable for wound dressing and hemostatic products. Wnek et al. have fabricated and characterized electrospun fibrinogen scaffolds [115], and found the fibrinogen mats to be composed of uniform, randomly orientated fibrinogen nanofibers. Notably, the electrospun fibrinogen fiber typically exhibited a granular appearance with $22.5 \mathrm{~nm}$ banding, characteristic of native fibrinogen. Consistent with the finding of studies using other polymers, the fiber diameter was shown to increase from 80 to $700 \mathrm{~nm}$ with increasing in polymer concentration. The electrospun fibrinogen mats were also shown to have substantial structural integrity and good handling, with an elastic 
modulus comparable to that of PGA. The most important characteristic of electrospun fibrinogen mats was their high surface area-to-weight ratio of $41000 \mathrm{~cm}^{2} \mathrm{~g}^{-1}$, making electrospun fibrinogen mats ideal for wound dressing products. However, the risk of immune cross-reactivity may limit the use of fibrinogen for scaffold applications.

Chitin and Chitosan Chitin and chitosan are biocompatible and biodegradable natural polymers, used in biomedical applications and cosmetics. Chitosan (polyD-glucosamine) is derived from chitin (poly- $N$-acetyl-D-glucosamine), a polysaccharide formed in shellfish exoskeleton, which has received more attention in biomaterial development than chitin due to its solubility. Therefore, chitosan has been critically considered as a candidate biomaterial for tissue engineering scaffolds [116-118]. Chitosan carries a high cationic charge density and can interact with various anionic polymers, such as chondroitin sulfate, to form a hydrogel scaffold [119]. Different from a hydrated scaffold, an electrospun scaffold is a preformed, nanofiber-based scaffold with a definite structure [120-122]. Min et al. used radiation to depolymerize chitin to increase its solubility for electrospinning [120]. In this study, the electrospun chitin nanofibers started to form at a viscosity at which the required polymer chain entanglement occurs. Fiber diameters vary from 40 to $600 \mathrm{~nm}$, but most fibers are less than $100 \mathrm{~nm}$. The authors also demonstrated that chitosan nanofibrous scaffolds electrospun using deacetylated chitin showed no significant changes in terms of scaffold size and fiber diameter after this transformation. Significantly different from Min's approach, Geng et al. directly electrospun a chitosan solution [122], prepared by dissolving chitosan in concentrated acetic acid, into chitosan nanofibers with an average diameter of $130 \mathrm{~nm}$. The authors suggested that the use of concentrated acetic acid to decrease surface tension of chitosan solution and increase the charge density of the jet, facilitated the formation of uniform chitosan nanofibers. Other factors affecting fiber morphology include chitosan molecular weight, solution concentration, and charge density of electric field. For each parameter, there is a narrow window of optimal working conditions for defect-free nanofiber formation to occur. Generally, a viscous chitosan polymer solution prepared from a higher molecular weight chitosan is preferred, with electrospinning done in a moderate charge density electric field.

Hyaluronan The most commonly used carbohydrate-based natural polymer in tissue engineering is hyaluronan (hyaluronic acid), a polysaccharide composed of repeating glucuronic acid and $N$-acetylglucosamine. Like chitosan, unmodified hyaluronan is hydrophilic and is commonly produced in a gel-format scaffold. A hyaluronan-based scaffold is inherently unstable and thus has limited application in tissue engineering. Thus, approaches have been developed to increase the resistance of hyaluronan to degradation, including esterification [123] and crosslinking [124]. Modified hyaluronan can be fabricated into scaffolds with pre-formed structures, and several in vitro and in vivo studies have reported cell proliferation and synthesis of ECM using these modified hyaluronan scaffolds $[125,126]$. It is difficult to form uniform size fibers from hyaluronan using electrospinning because of 
the high viscosity and surface tension of the hyaluronan solution. Um et al. reported on several approaches to prepare a hyaluronan solution that has sufficient molecular entanglement in a rapidly evaporated solvent, while still maintaining low viscosity and surface tension [127]. One of the approaches blended two hyaluronan polymers of low and high molecular weight, resulting in increased molecular entanglement but not viscosity. Another approach consisted of adding ethanol in the polymer solution, which facilitated solvent evaporation as well as reduction in surface tension. However, although the approaches seemed rational, these results, while satisfactory, were limited. Therefore, further approaches entailed adding an air-blow system close to the spinneret, providing both electrical and air-blowing shear forces as well as heat, to facilitate hyaluronan nanofiber formation, and the new setup is named an "electro-blowing" system. In the electro-blowing apparatus, the hyaluronan solution was heated to reduce viscosity and surface tension, and was electrospun by both electrical (voltage) and mechanical (air blow) force. Lastly, air-blowing significantly improved solvent evaporation and fiber stretch, and the electro-blowing system produced hyaluronan nanofibers with a fiber diameter ranging from 49 to $74 \mathrm{~nm}$.

\subsubsection{Synthetic Polymeric Nanofibrous Scaffolds}

Poly ( $\alpha$-hydroxy esters) The most commonly used biopolymers for nanofiber production are of the biodegradable poly $(\alpha$-hydroxy ester) based polymer family. PLA, PGA, their co-polymers, poly(lactic-co-glycolic acid) (PLGA), and poly( $\varepsilon$ caprolactone) (PCL) are biodegradable polymers approved by the U.S. Food and Drug Administration, with a long history in medical applications. In vivo, complete degradation of $\operatorname{poly}(\alpha$-hydroxy esters) results in the production of natural metabolites, such as lactic acid, which are subsequently converted into $\mathrm{CO}_{2}$ and water, and eventually removed by the respiratory and urinary systems, respectively [128]. Thus, poly( $\alpha$-hydroxy esters) are metabolized into non-toxic end-products that are not accumulated in the body.

PGA is a polymer of glycolic acid and has been extensively used in various biomaterial applications. Due to its high crystallinity, it is insoluble in general organic solvents, with highly fluorinated solvents being the only exception. Consistent with the trend found in other polymers, the PGA fiber diameter, ranging from $110 \mathrm{~nm}$ to $1.19 \mu \mathrm{m}$, increases with polymer concentrations from 0.05 to $14.3 \mathrm{wt} . \%$. PGA polymer in a higher concentration solution encounters stronger molecular entanglement, resulting in thicker fibers during the electrospinning $[129,130]$.

PLA, with the addition of a methyl group, is more hydrophobic and more soluble in organic solvents, and degrades more slowly than PGA [131]. The three stereoisomers of PLA [D, L, and D,L] differ in the position of a methyl group in the lactic acid monomer, and exhibit distinct properties. For example, PLLA has a higher melting temperature than PDLLA because of its higher order crystal structure. However, PDLLA, composed of 1 and d stereoisomers, degrades faster than PLLA. The properties of various PLA polymers are determined by the stereochemistry of the PLA isomers. PLLA is a semicrystalline polymer, whereas PDLLA is an 
amorphous polymer. During the preparation process, both PLLA and PDLLA are soluble in most organic solvents, such as chloroform. Commonly, DMF is added to increase the polymer conductivity, enhancing the fiber formation. Electrospun PDLLA and PLLA fibers share similar morphology, fiber density (0.27-0.31 $\mathrm{g} \mathrm{cm}^{-3}$ ), and porosity (75-78\%) [132]. However, the average diameter of semicrystalline PLLA fibers is larger than that of amorphous PDLLA fibers when both polymers are used at the same concentration, suggesting that a stronger polymer molecular entanglement exists in PLLA fibers.

PLGA is a widely used biodegradable polymer because of its flexibility of copolymerizing different ratios of PLA and PGA. Depending on the ratio of copolymerization, PLGA has different subtypes with each exhibiting different properties. PLGA has been extensively used in medical products and was one of the first biodegradable polymers electrospun for tissue engineering applications [133]. The PLGA copolymer has an amorphous structure, because the constituent PGA and PLA molecules are unable to pack tightly to one another. Katti et al. and Berkland et al. have both used PLGA for electrospinning to investigate the parameters affecting fiber morphology $[134,135]$. Their results showed that, in addition to polymer concentration and charge density, orifice diameter also has an effect on the morphology and diameter of electrospun fibers. Smaller nanofibers tend to be produced from smaller orifices. The area density of electrospun fiber mats increases linearly with electrospinning time. Among the working parameters, polymer concentration is the major parameter affecting fiber morphology. Li et al. have shown that nanofibrous PLGA scaffolds have an interconnected-porous structure with more than $90 \%$ porosity and sound mechanical properties, ideal properties for tissue engineered scaffolds [25].

Another member of the poly( $\alpha$-hydroxy ester) family is $\operatorname{poly}(\varepsilon$-caprolactone $)$ (PCL), also a semicrystalline biodegradable polymer. Compared to other polyester family members such as PLA, PGA, and PLGA, PCL has been used less frequently as a material for fabricating biomaterial scaffolds, mainly because of concern over its slower degradation kinetics [136]. However, the improved resistance to hydrolytic attack and lower cost than other biodegradable polymers also make PCL an attractive polymer for the fabrication of electrospun nanofibers $[53,77,99,100$, 137-146]. The rationale for using a biodegradable polymer with a longer half-life is to provide a structurally stable environment that is able to initiate and promote cell growth for a sufficient period of time. Lee at al. characterized the morphology, crystallinity, and mechanical properties of electrospun PCL meshes produced by electrospinning PCL solutions prepared in different solvents; they found that surface tension, viscosity, and electric conductivity of PCL solutions depended on the addition of DMF [53]. DMF can efficiently enhance the electrospinning process by decreasing fiber diameter by decreasing the surface tension and viscosity of the polymeric solution, and also by increasing polymer conductivity and the dielectric constant. It is also known that the electrospinning process reorganizes PCL polymer chains and, compared with unprocessed PCL, electrospun nanofibers have a reduced crystallinity.

Although poly( $\alpha$-hydroxy ester $)$ members are classified in the same polymer fam- 
ily, electrospun scaffolds derived from these polymers exhibit distinct degradation and mechanical properties $[25,129,132,147]$. Studies comparing the degradation of electrospun nanofibers of various poly( $\alpha$-hydroxy esters) have shown that PLLA and PCL fibers were able to resist hydrolytic attack for the duration of the study. However, all of the remaining polymers underwent severe degradation, including both structural collapse and gross shrinkage. A similar study conducted by Zong et al. demonstrated that PLGA 75:25 and PDLLA degrades at a much faster rate than PLGA 10:90 and PLLA [132]. One of the reasons for this more rapid degradation could be the high surface area of nanofibrous scaffolds, thereby allowing more water contact at the polymer surface, accounting for the vulnerability of small fibers, like nanofibers, to hydrolytic attack. Zong et al. also proposed that the electrospinning process lowers the glass transition temperature of PLGA copolymers to a value very close to their incubation temperature $\left(37^{\circ} \mathrm{C}\right)$; the relaxation of extended amorphous chains near the glass transition temperature thus causes shrinkage under incubation condition. Given the rapid degradation of some nanofiber formulations, many research groups have focused their efforts on electrospinning PLLA or PCL alone, or copolymerized with other biodegradable polymers, to fabricate polymer scaffolds with more desirable, long term stability.

Poly(3-hydroxybutyrate-co-3-hydroxyvalerate) (PHBV) PHBV is a member of the polyester family, and represents a new class of biodegradable polymers, recently attracting attention for tissue engineering applications. The co-polymerization with hydroxyvalerate renders PHBV with enhanced mechanical and degradation properties, thus extending the application to scaffold fabrication. Choi et al. investigated the feasibility of PHBV electrospinning and attempt to reduce fiber diameter by increasing the conductivity of the polymeric solution [54]. PHBV fibers electrospun from various concentrations of polymeric solutions range from 1 to $4 \mu \mathrm{m}$. However, efforts to manipulate electrospinning parameters such as voltage and concentration were not effective in bringing the fiber diameter below $1 \mu \mathrm{m}$. To increase the conductivity of the polymeric solution, favorable for smaller fiber formation, benzyl triethylammonium chloride (BTEAC) was added to the PHBV solution. The addition of BTEAC resulted in a reduction of the size of the electrospun fibers and the needed polymer concentration for producing uniform fibers, suggesting the conductivity of the PHBV solution plays a major role affecting the fiber diameter and morphology of PHBV fibers. In addition, the degradation of the electrospun fibrous mat is relatively slow in the first 12 days, but the disintegration of the structure accelerates after that, and results in a dramatic weight loss.

Poly(ethylene-co-vinyl alcohol) (PEVA) PEVA is a semi-crystalline, biocompatible but not biodegradable polymer. Recently, it has been electrospun and evaluated for its potential in tissue engineering scaffolds. PEVA is a hydrophilic polymer that is insoluble in aqueous solution due to the presence of both vinyl alcohol and ethylene groups. Most hydrophobic polymers have the property of slow degradation, whereas most hydrophilic polymers exhibit a rapid degradation rate. The de- 
sired property makes PEVA a potential material ideal for tissue engineering scaffolds. PEVA needs to be dissolved in dimethyl sulfoxide or lower alcohols. Kenawy et al. have prepared the PEVA solution by dissolving PEVA in a $70 \%$ alcohol solution (rubbing alcohol) at $65^{\circ} \mathrm{C}$ for electrospinning [148]. Interestingly, the polymer tends to precipitate when sitting in room temperature for several hours. Therefore, electrospun PEVA needs to be processed before precipitation occurs, and is carried out in a setup designed to maintain the solution temperature. This study also demonstrated a consistent finding of fiber diameter increasing with increase in solution viscosity. The diameter of fibers electrospun from higher concentrations of polymer solutions is higher than the $\mu \mathrm{m}$ level. In these structures, fibers are fused at their contact points, instead of being individually stacked, suggesting that strong molecular entanglement exists in the highly concentrated PEVA polymer solution. Another remarkable observation is that PEVA electrospinning is extremely efficient. The usage of PEVA, disinfected by dissolving in rubbing alcohol, combined with the efficiency of the PEVA electrospinning, could be ideal for wound dressing application.

Poly(ethylene terephthalate) (PET) PET, referred to also by the trade name "Dacron", has largely been used in biomaterial applications, especially in blood vessel prostheses, since PET is inert and does not interact with blood cells. Ma et al. investigated how electrospinning time affects the thickness and porosity of electrospun PET scaffolds [98]. The electrospun PET nanofibers fabricated using optimal parameters ranged from 200 to $600 \mathrm{~nm}$. The thickness, mass per area, and porosity of the PET fiber mats all increase with increasing electrospinning time. However, there is no linear relation between these factors. A likely explanation is that not all the as-spun nanofibers were collected onto the sampling area, because, in their setup, there was uneven fiber deposition onto the fiber-collecting surface.

Polyurethane (PU) PU is a non-biodegradable biomaterial with good blood and tissue compatibility, which is primarily used in vascular implants or wound dressing. $\mathrm{PU}$ is ideal for applications for tissue engineering products that require stable mechanical properties or structural integrity. Unlike most studies in which the polymer concentration was manipulated to control fiber morphology, Khil et al. have optimized fiber morphology by controlling solvent composition [149]. They electrospun a PU solution, prepared from pure DMF or tetrahydrofuran (THF) or mixed solvents with different DMF/THF ratios, and found that the mixed solvent produced more uniform, small fibers. Electrospun fibers prepared from pure DMF were smaller and irregular, whereas those from pure THF were relatively larger and uniform. Solvents could loosen the polymer coil, thereby affecting the viscosity of a polymer solution. In this study, the different solvent compositions loosened the polymer coil to various extents, resulting in different viscosities. The mixed solvent reduced the surface tension and viscosity of PU solution, and the addition of DMF increased the conductivity of the solution, which together contributed to the formation of uniform fibers. 
Poly(ethylene oxide) (PEO) PEO is a commonly used biomaterial for tissue engineering because of its capability to gel in situ. A PEO gel can be directly injected into an irregularly shaped defect site and photopolymerized to help tissue repair $[150,151]$. However, the inherent, soft mechanical properties of the PEO hydrogel and the depth limit of the injection site that permits sufficient energy present a major challenge for using PEO hydrogel. Preformed PEO scaffolds with a defined porous structure is another scaffold option. PEO is one of the earliest polymers processed for electrospinning because it is easy to prepare and can be dissolved in both organic and aqueous solvents. Much of the current knowledge on the electrospinning process is in fact based on results using PEO. Because of the ease of forming uniform nanofibers, PEO, is often blended with another polymer in the electrospinning of tissue engineering scaffolds $[106,152,153]$.

\subsubsection{Composite Polymeric Nanofibrous Scaffolds}

Current scaffold development aims to incorporate many polymer types for the fabrication of biomaterial scaffolds that are able to respond to the biological activities of cells while meeting specific host tissue site requirements. Regardless of whether a double, triple, even quadruple polymer blend/mix is used, a tissue engineering scaffold made of a polymer blend should still retain the properties of each polymer type. Therefore, it is expected that electrospinning of a polymer blend/mix will create novel composite scaffolds with enhanced performance for tissue engineering. Another practical reason for electrospinning a blend of polymers is that often the polymer of interest cannot be electrospun into uniform fibers without the addition of the "electrospinning-driving" polymer. Regardless of the goal, the challenge of electrospinning a polymer blend is to optimize the standard electrospinning parameters, which are further complicated by the interplay of the properties of multiple polymers. Hence, a sound understanding of polymer and solvent chemistry is important in identifying favorable electrospinning parameters. Three general composite nanofibrous scaffolds, natural-natural, synthetic-synthetic, and naturalsynthetic, have been developed and characterized for their properties and potential applications.

Natural-Natural Composites Electrospinning of multiple natural polymer blends can yield a mixture of natural nanofibers that closely mimic the native ECM. A large percentage of native tissues contains both collagen and elastin fibers that are frequently subjected to tensile and elastic loading, respectively. Electrospun fibrous scaffolds composed of collagen types I and III, and elastin have been fabricated to replicate the native ECM of blood vessels [94]. The fiber diameter found within the native ECM of blood vessels ranges from 270 to $710 \mathrm{~nm}$, which is slightly larger than the 100 to $680 \mathrm{~nm}$ diameter range of nanofibers electrospun from blends of collagen types I and III. Aside from protein-protein mixtures, the protein-based silk and carbohydrate-based chitosan blend has been electrospun into nanofibers as well. In the silk fibroin/chitosan blend for electrospinning, the addition of chitosan increases the viscosity and conductivity of the blend solution, thus enhancing the formation of smaller, uniform nanofibers [111]. One possible explanation for 
this phenomenon is that chitosan carries ionizable, amino groups, and increases the conductivity of the silk fibroin, which is ideal for electrospinning. Nevertheless, the formation of uniform nanofibers discontinues after excessive chitosan is added. Silk fibroin and chitosan in the blend solution may form hydrogen bonds, suggesting that optimizing the electrospinning of a blend natural polymer is more complicated than for pure natural polymers. It is reasonable to expect that the nanofiber mat is composed of individual, blended nanofibers rather than a mixture of different mono-polymer nanofibers.

Synthetic-Synthetic Composites The synthetic-synthetic blend is commonly used to fabricate scaffolds with the combined properties of composite polymers. Polymers, such as PLA and PCL, are biodegradable, biocompatible, and hydrophobic whereas poly(ethylene glycol) (PEG) is hydrophilic, non-immunogenic, and nonbiodegradable. In mixing PLA and PEG, the resultant PLA/PEG blend is more hydrophilic than PLA and also more biodegradable than PEG. In addition, the coexisting properties of hydrophilicity and biodegradability can be programmed by manipulating the ratio and the type of composed polymers. For instance, PLGA nanofibrous scaffolds shrink during degradation; thus, by blending of PLGA and PEG-PLA one can effectively resist scaffold shrinkage [154]. In addition to improvements in biodegradation, the polymer blend has been shown to exhibit flexible mechanical properties that can be altered by the ratio of composed polymers. For example, the elastic PEVA nanofibrous mat becomes stiffer after PLA is added for blend electrospinning [155].

Natural-Synthetic Composites The mixing of natural and synthetic polymers can be a major challenge for electrospinning since solvents workable for both polymers are limited. Therefore, the choice of solvent becomes a primary consideration after determining the blend components. Many natural polymers are difficult to electrospin into nanofibers, especially when dissolved in water, since their polyelectrolyte characteristic interferes with fiber formation. One alternative is to add synthetic polymers such as PEO to facilitate nanofiber formation. The natural polymer/ PEO blend in aqueous solution can be electrospun, and the use of organic solvents may be avoided. Duan et al. have systematically characterized the properties of chitosan/PEO blend solutions and their electrospun fibers [153]. They concluded that the chitosan/PEO blend retains conductivity, surface tension, and viscosity, and favors the formation of smaller, uniform nanofibers, compared with pure chitosan or PEO solutions.

Another completely different blending approach is to physically, rather than chemically, mix two polymer nanofibers together using multiple jet electrospinning. In this approach, natural and synthetic polymers are placed in two separate containers and electrospun simultaneously to form a natural/synthetic nanofibrous composite. For example, poly(vinyl alcohol) (PVA) and cellulose acetate (CA) are electrospun onto the same target area [156]. With this method, PVA and CA nanofibers disperse into each other as a direct result of physical blending. When the PVA/CA ratio of the blend is reduced, mechanical properties, such as tensile 
strength and fiber elongation, are decreased, but the average fiber diameter increases. Further investigations are needed to assess whether the mechanical property changes are due to polymer composition, fiber size, or a combination of the two.

\subsubsection{Nanofibrous Scaffolds Coated with Bioactive Molecules}

A natural ECM scaffold contains bioactive peptides, such as RGD sequences, but is often mechanically too weak or rapidly degraded for tissue engineering applications. Conversely, a synthetic polymeric scaffold has tailorable properties to meet the physical requirements, but lacks the native biocompatibility. There is, therefore, a need to develop methodologies to incorporate and optimize bioactive motifs, such as the RGD peptide, for the synthesis of biocompatible polymeric scaffolds that possess the advantages of both natural and synthetic polymers. Unlike natural-synthetic composite nanofibrous scaffolds fabricated from electrospinning a blend polymer, nanofibrous scaffolds coated with bioactive molecules are produced by coating natural polymers to the surface of synthetic nanofibrous scaffolds. This after-work addition can avoid alteration of the properties of the natural polymer during the electrospinning. The most commonly used approaches for the incorporation of bioactive agents on a polymeric surface include simple coating and covalent linking. The simple coating process is easy and fast but the coated agents detach shortly, depending on the coating surface properties, whereas the covalent linking process is more laborious but the coating should be more stable.

Collagen coated electrospun scaffolds have been developed by simply placing nanofibrous scaffolds in a collagen solution. The simple coating works for most synthetic polymers, but the efficiency and effectiveness of the coating are dependent on polymer surface properties such as charge, chemistry and geometry. Collagen type I has been coated on PCL [142] and P(LLA-CL) [157] electrospun nanofibrous scaffolds, which are used for culturing different cells for various tissue engineering applications. Although there is no direct measurement to evaluate the efficiency of the collagen coating on the scaffolds, cell response, i.e., the promotion of specific biological activities, indirectly demonstrates the presence of collagen coating on electrospun fibrous scaffolds.

Electrospun nanofibrous scaffolds made of either hydrophobic or hydrophilic synthetic polymers are usually inert and lack functional groups for direct covalent linkage of bioactive peptides or domains. To create functional groups for the covalent bonding, surface processing techniques, such as acid/base treatment, chemical activation, and oxidization, are used. For instance, studies have reported on the modification of PET nanofiber surfaces by gelatin grafting [98]. The process starts with the creation of hydroxyl groups on PET nanofibers using formaldehyde, grafts with methacrylic acid, and covalent linkage of gelatin using carbodiimide. The results show that more gelatin is grafted to PET nanofibers than to the film counterpart, and the grafting occurs throughout the entire scaffold surface. In addition, gelatin grafting significantly increases the hydrophilicity of the PET surface, suggesting that covalently grafting bioactive proteins or peptides to a nanofibrous scaffold is an effective approach for the modification of the hydrophobic properties of the scaffold. 
3.3 .3

Engineered Tissues using Electrospun Nanofibrous Scaffolds

\subsubsection{Skin}

Skin is the largest tissue covering the body and provides physical and chemical protection of the body from harmful sources such as heat and microbial organisms. The top layer is the epidermis containing melanocytes and the dermis lies directly underneath the epidermis.

In the body, cells and tissue matrices interact via complex chemical and physical processes. Due to the sophisticated architecture of the skin with its various layers, it is difficult for current synthetic 3D matrices to simulate such processes. Therefore, electrospinning has been used to spin natural and synthetic polymers to fabricate biomaterial scaffolds that more closely mimic the tissue matrix of skin. In a study by Venugopal et al., PCL, collagen type I, and collage type I-coated PCL nanofibers were electrospun to fabricate a substitute for skin regeneration [144]. In this study, fibroblasts from normal human skin attached and spread on all three nanofiber matrices; however, the interaction between cells and nanofiber matrices varied with the scaffold material. For instance, collagen nanofiber matrices showed a significantly higher level of fibroblast proliferation than control monolayer culture. Conversely, PCL fibers showed a significantly lower level of cellular proliferation than control monolayer culture. The results of this study also showed normal morphology and confluence of cells on control monolayer culture and collagen nanofibers. However, while PCL nanofibers were able to support cell growth, they showed no confluence compared with collagen coated PCL nanofibers. As a result, this study proved that PCL fibers are able to partially support the growth of skin fibroblasts, while the presence of collagen on the scaffolds greatly enhances the interactions between cells and nanofibers. The advantage of using a collagen coated PCL composite nanofibrous scaffold is to incorporate the biological and mechanical properties of each polymer, with collagen type I providing a favorable milieu for skin fibroblasts and biodegradable PCL improving the mechanical integrity of the matrix. Therefore, electrospun 3D nanometer sized fibers provide a potential scaffold for skin regeneration. Min et al. electrospun silk fibroin into nanofibers and then coated the fibers with collagen type I, fibronectin, and laminin to evaluate cell response to different ECM coatings on silk fibroin nanofibers [109]. In addition, they also used different cell types, human oral and epithelial keratinocytes and gingival fibroblasts, to measure cell attachment and spreading on the nanofibers. In terms of the effect of various ECM coatings, collagen type I coated nanofibers were shown to more actively promote attachment of keratinocytes, compared with laminin or fibronectin coated nanofibers, and, interestingly, even to a polystyrene surface. Cells adhered to and spread on the surface of silk fibroin nanofibers, and then started to migrate along the fibers, forming a 3D cellular network well integrating with nanofibers. The similar cellular response in a nanofiber scaffold is also demonstrated in the previous study using fibroblasts in PLGA nanofibers [25]. Beside the attempt of using silk fibroin nanofibers as scaffolds for skin regeneration, chitin/PLGA nanofibrous scaffolds cultured with keratinocytes 
and fibroblasts have also shown great promise in skin tissue engineering since chitin has proved to have good wound healing properties [158]. The chitin/PLGA nanofibrous scaffolds, taking advantages of the desired properties of chitin and PLGA for tissue engineered scaffolds, exhibit improved hydrophilicity and sound mechanical properties. Cells attach better in the chitin/PLGA than the PLGA-only nanofibrous scaffolds. In the preliminary cell study, the same cell types used in the silk fibroin scaffolds show a similar trend of cell attachment and spreading in various ECM coated chitin/PLGA nanofibrous scaffolds. Collagen type I coated chitin/ PLGA nanofibrous scaffolds enhances cell attachment and spreading in the scaffolds, which is critical for cellular activities in skin regeneration using the tissue engineering approach.

\subsubsection{Blood Vessel}

Blood vessels are a part of the circulation system, and function as a channel to transport oxygen and nutrient to the body tissues or remove metabolic waste for replenishment. There are three types of blood vessels found in the body: arteries, veins, and capillaries. Each of them has a different structure and various functions. Vascular related disorders are one of the leading fatal diseases around the world, and one of the current treatments is the use of vascular grafts in bypass surgeries. In terms of material types, grafts are either biological (autograft, allograft, and xenograft) or synthetic. Although there is fair success with these conventional grafts, challenges such as the availability of small vascular grafts still remain. Vascular tissue engineering is promising for creating cellular vascular grafts with desired dimensions.

The tissue engineered artery fabricated using electrospun scaffolds has been extensively investigated recently. Boland et al. have fabricated a vascular scaffold by assembling two electrospun nanofibrous tubes composed of different collagen/ elastin ratios with cultured dermal fibroblasts, aortic smooth muscle cells, and umbilical vein endothelial cells in the outer, middle, and inner layers of the scaffold, respectively, to simulate the anatomical three layers of an artery [94]. After culturing in a bioreactor, the engineered artery exhibits a tri-cellular layer architecture in cross section. One of the critical requirements for tissue engineered arteries is to have satisfactory mechanical properties to bear compliance strength and burst pressure. Therefore, Stitzel et al. blended PLGA with collagen and elastin to produce an electrospun tri-polymeric fibrous scaffold, thus increasing the strength of the original collagen/elastin scaffold and rendering it mechanically comparable to a native artery [102]. Both endothelial and smooth muscle cells cultured in the scaffolds exhibit favorable cell attachment and growth. Further in vivo testing found no signs of toxicity. In addition to studies that focus on the design of a tissue engineered vascular graft, several studies have reported the effects of surface roughness and fiber orientation on the cellular activities of vascular cells [159, 160]. Xu et al. have demonstrated that endothelial cells cultured on electrospun fibrous scaffolds exhibit less-spread cell morphology, compared with those on smooth surfaces [159]. An increase in cell attachment and proliferation was also observed on the smooth surface culture. Another study has shown that smooth 
muscle cells exhibit a spindle-like contractile phenotype, while cytoskeletal proteins, such as $\alpha$-actin and myosin filaments, are oriented along the direction of aligned nanofibers [160]. Fiber alignment using electrospinning supports the construction of a tissue engineered vascular graft that contains a middle, smooth muscle layer that mimics the circumferentially oriented nature.

\subsubsection{Cartilage}

Adult cartilage is formed mainly at the articular joint and is a specialized tissue that consists of chondrocytes, ECM macromolecules, and water. Chondrocytes synthesize and maintain the ECM in cartilage while the ECM functions to provide structural protection to residing cells and to act as a regulatory messenger for cell activities. Cartilage tissue engineering aims to replace damaged cartilage and restore biological function. A main research focus in our laboratory is the development of cartilage tissue engineering using the electrospinning technique.

We have recently compared the biological response of chondrocytes seeded onto 3D PCL nanofibrous scaffolds to that of cells seeded as monolayers on standard tissue culture polystyrene (TCPS) [77]. Gene expression analysis (Fig. 3.5) showed that chondrocytes seeded on the nanofibrous scaffold maintained their chondrocytic phenotype by expressing cartilage-specific ECM genes, including collagen types II and IX, aggrecan, and COMP. Specifically, expression of the collagen type IIB spliced variant transcript, indicative of the mature chondrocyte phenotype, was significantly up-regulated. Chondrocytes exhibited a round shape on the nanofibrous scaffolds, in contrast to a flat, well-spread morphology seen in monolayer

\section{DAY CARTILAGE-SPECIFIC GENE EXPRESSION}

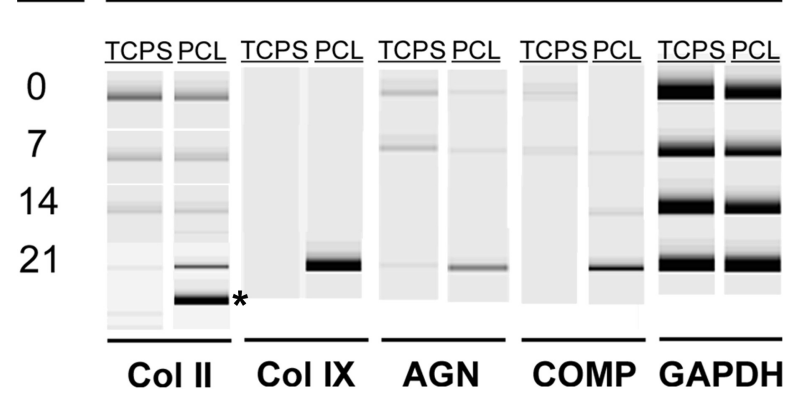

Fig. 3.5. Reverse transcription-polymerase chain reaction (RT-PCR) analysis of expression of cartilage associated genes in fetal bovine chondrocytes seeded onto tissue culture polystyrene (TCPS) or PCL nanofibrous scaffolds. On culture days $0,7,14$, and 21 total RNA was extracted and RT-PCR performed with gene-specific primer pairs, including collagen type II (Col II), collagen IX (Col IX), aggrecan $(A G N)$, cartilage oligomeric matrix protein
(COMP), and glyceraldehyde-3-phosphate dehydrogenase (GAPDH) as a house keeping gene. Cells cultured on nanofibrous scaffolds showed strong induction of mRNA expression of collagen types II and IX, aggrecan, and COMP after 21 days. More importantly, the alternatively spliced mRNA variant of collagen type II, the IIB $(*)$, was expressed only in the nanofibrous scaffold cultures. 
172 | 3 Electrospinning Technology for Nanofibrous Scaffolds in Tissue Engineering

H \& E

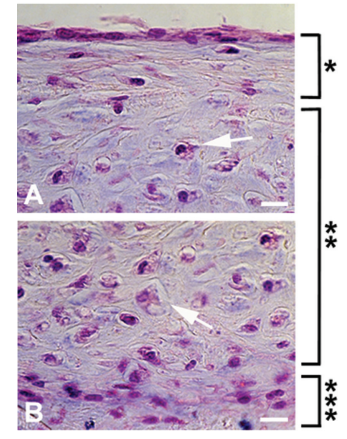

Alcian Blue

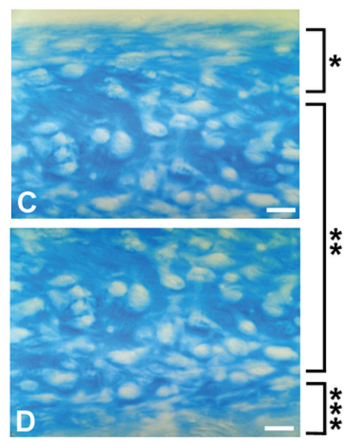

Fig. 3.6. Histological analysis of MSC cultures seeded into a PCL nanofibrous scaffold and maintained in a chondrogenic medium supplemented with TGF- $\beta 1$ for 21 days. Sections from the upper and lower portions of the 3D constructs were stained with hematoxylin and eosin (H\&E) (A, B) and Alcian blue (C, D). H\&E staining showed flat fibroblast-like cells on the top zone (*), round chondrocyte-like cells embedded in lacunae (arrows) in the middle zone ( $(* *)$, and small, flat cells at the bottom zone (****). Alcian blue staining showed the presence of sulfated proteoglycan-rich ECM in the construct. Bar $=10 \mu \mathrm{m}$.

cultures on TCPS. Histologically, nanofibrous cultures produced more sulfated proteoglycan-rich, cartilaginous matrix than monolayer cultures. These results indicate that the biological activities of chondrocytes are crucially dependent on the dimensionality of the extracellular scaffolds, and that nanofibrous PCL may be a biologically preferred scaffold/substrate for proliferation and phenotype maintenance of chondrocytes.

In another study [140], we specifically compare the chondrogenic activities of MSC-nanofiber cultures to those of high-density cell pellet cultures, a commonly used culture system for studying chondrogenesis of MSCs in vitro. MSCs cultured in nanofibrous scaffolds in the presence of TGF- $\beta 1$ differentiate into a chondrocytic phenotype, as evidenced by chondrocyte-specific gene expression and the synthesis of cartilage-associated ECM proteins. The level of chondrogenesis observed in MSCs seeded within nanofibrous scaffolds is comparable to that observed for MSCs maintained as cell aggregates or pellets. The 3D MSC-seeded constructs display a cartilage-like morphology, containing chondrocyte-like cells surrounded by abundant cartilaginous matrix (Fig. 3.6). Due to the physical nature and improved mechanical properties of nanofibrous scaffolds, particularly in comparison to cell pellets, these findings suggest that the nanofibrous scaffold is a practical carrier for MSC transplantation, and represents a candidate scaffold for cell-based tissue engineering approaches to cartilage repair.

\subsubsection{Bone}

Bone is a hard, solid connective tissue that provides structure and protection to the body. To support external loading and absorb shocks, bone has a unique structure 
and chemical composition. The bone structure is composed of two layers of different density of bones. The outer layer is compact bone and the inner layer being spongy bone. Bone is always undergoing dynamic remodeling carried out by two different cell types, the osteoblast for building bone and the osteoclast for digesting bone. In addition, the bone marrow contains numerous MSCs that are capable of differentiating into various connective tissue cells to replenish them.

Cells used in bone tissue engineering include osteoblasts, osteoprogenitor cells, and MSCs. Each of these cell types, depending on their nature, requires a different culture environment. MSCs are a highly promising cell source for tissue engineering applications because of their multi-differentiation capabilities and their expandability [81]. Applications of MSCs for bone tissue engineering requires that the cells are seeded within electrospun nanofibrous scaffolds that will permit and/ or promote osteogenic differentiation. Yoshimoto et al. and Shin et al. have reported on the osteogenic differentiation of MSCs in PCL nanofibrous scaffolds cultured in vitro and in vivo $[137,138]$. In their study, MSCs from rat bone marrow seeded in PCL nanofibrous scaffolds are cultured in a rotatory oxygen-permeable bioreactor with the osteogenic medium. This environment promotes MSCs to differentiate into osteoblast-like cells producing collagen type I and minerals in the scaffold. In addition, the bioreactor improves oxygen and nutrients diffusion, enhancing cell growth in the nanofibrous scaffold. Initial osteogenic differentiation of MSCs is carried out in the in vitro model. Further assessment of bone formation included implanting the MSC loaded nanofibrous scaffold pre-induced and -cultured in a bioreactor in a rat model. The new osteo-matrix is deposited throughout the entire harvested cellular constructs, resulting in a white, smooth appearance and stiffer properties. The preliminary results of new bone formation using MSC-nanofiber constructs are encouraging. To actively induce bone formation, osteoconductive calcium carbonate has been coelectrospun with PCL nanofiber to fabricate a nanofibrous composite scaffold. The addition of calcium carbonate increases the mineralization in the cellular constructs, an early sign of bone formation. The composite scaffold combining the osteogenic promotion of nanofibers and the osteoconductivity of calcium carbonate is also suggested for guided bone regeneration therapy to repair jaw and alveolar bone defects.

\subsubsection{Muscle}

Muscles make up most of the body and account for almost half of body weight. Skeletal muscle covering the skeleton functions to move the body, cardiac muscle making up the heart contracts in a rhythmic movement, and smooth muscle forming internal organs perform the unconscious actions. The three types of muscles are composed of different kinds of cells and ECM protein compositions.

Skeletal muscle tissue is composed of bundles of highly oriented and dense muscle fibers, each representing a multinucleated cell derived from myoblasts. Therefore, the engineering of skeletal muscle tissue necessitates the use of a biomaterial scaffold that will allow cells to align parallel to one another. Electrospinning, as previously illustrated, provides a technique that not only can generate nanoscale non-woven fibers, but this technique also offers the versatility of align- 
ing fibers to yield an ideal scaffold architecture for skeletal muscle tissue engineering. In a study by Riboldi et al., DegraPol®, a degradable block polyesterurethane, was electrospun to fabricate a biomaterial scaffold to engineer skeletal muscle tissue using mouse C2C12 muscle progenitor cells [161]. Preliminary experiments in this study found $\mathrm{C} 2 \mathrm{C} 12$ line cells to be compatible with the electrospun scaffold by adhering, proliferating, and differentiation into myotubes on the electrospun scaffolds [161]. More specifically, the authors showed that after 3 days of culture of $\mathrm{C} 2 \mathrm{C} 12$ cells in differentiation medium there was formed elongated, multinucleated, myosin heavy chain expressing myotubes that preferentially aligned with the direction of the scaffold fibers. $\mathrm{C} 2 \mathrm{C} 12$ cells were also viable on the electrospun scaffold up to 7 days of culture. By aligning myofibers to one another, scaffolds may be engineered with the ability to generate sufficient force for contraction of differentiated $\mathrm{C} 2 \mathrm{C} 12$ cells. While the tendency of utilizing microfibrous polymeric scaffolds has yielded promising results in driving myofibers development and orientation along the scaffold, the high tensile modulus and low-yield elongation of these microfibrous polymeric scaffolds is inadequate to withstand the mechanical stimulation needed for dynamic culturing methods needed for skeletal muscle tissue engineering [161-163].

A critical factor for successful regeneration of myocardium in a tissue engineered scaffold is that the scaffold structure should be flexible for cardiomyocyte contraction, sustain a reasonable tension for cell morphology maintenance, and have a good integrity for handling. To fulfill this purpose, Shin et al. have cultured primary cardiomyocytes from rat ventricles on PCL nanofiber suspended wire rings [139]. Interestingly, unlike a rigid scaffold, the flexibility of the nanofibrous network applies limited restriction on cell contraction. The cardiomyocytes on the nanofibers start the ubiquitous and synchronized contraction after 3 days of culture. In addition, cells within the scaffold exhibit spindle, multi-angular musclecell-like morphology, and also express cardiac-specific markers such as tropomyosin and connexin43. The wire ring applies a tensile force on the suspended nanofibers, which may be transferred to stretch cells, which is critical for the maturation of the cardiomyocyte. In another study, rat cardiac fibroblasts are cultured in acid-treated PGA scaffolds to evaluate the proliferation of cells cultured in PGA scaffolds with different fiber sizes and surface chemistry [130]. Cells proliferate significantly more rapidly in acid treated, smaller nanofibers, suggesting that the acid treated surface exposes more carboxylic and hydroxylic groups that favorably attract cell attachment molecules, such as fibronectins and vitronectins, to enhance cell attachment; thus more cells can grow on a bigger surface area in a scaffold with smaller fibers.

Functional tissue engineered smooth muscle is essential for the development of complex tissue engineered organs. Flexible, anisotropic properties of smooth muscle provide internal organs the capability of constant movement and the expansion for additional content storage. Electrospinning has been applied to microintegrate smooth muscle cells into nanofibrous scaffolds to fabricate a cell-nanofiber composite [44]. The mechanical properties of the composite are in an adequate range to meet the requirements for soft tissue application. After culturing in a perfusion 
bioreactor, the cellular composite exhibits a high density of smooth muscle cells in a uniform distribution. The smooth muscle is successfully engineered by the microintegration process based on the electrospinning, which can be adopted to tissue engineer other tissues as well.

\subsubsection{Ligament}

The ability of electrospun nanofibrous scaffolds to mimic the architectural scale of the native ECM provides them with great potential for the engineering of ligaments. The ligament is a tough fibrous band of slightly elastic connective tissue that provides stability to skeletal joints. The specialized cells that make up ligaments are called fibroblasts. The matrix of ligaments is made up of collagen fibrils with a diameter of $\sim 60 \mathrm{~nm}$; therefore, nanofibrous scaffolds should provide ligament fibroblasts with a structure that closely mimics the native matrix [164]. A study investigating the effects of fiber alignment on the ECM generation of human ligament fibroblasts (HLF) on PU electrospun nanofibers showed that cells cultured on aligned nanofibers were spindle-shaped and oriented in the nanofiber direction, while cells on non-aligned nanofibers had no directionality [164]. After 7 days of culture, HLF cells on aligned nanofibers showed a significant change in their ECM with increase collagen synthesis compared with non-aligned fibers, although cell proliferation was not affected by fiber directionality [164]. A significant increase in cell attachment and proliferation on nanofiber scaffolds was also observed, as compared with cast PU membranes. Therefore, this study demonstrates that the biomimetic nature of aligned electrospun nanofibers provides an architectural environment similar to that which ligament fibroblasts normally encounter in vivo.

\subsubsection{Nerve}

Unlike other parts of the body, the central nervous system (CNS) cannot generate new neurons or regenerate damaged nerves itself. Cell-based tissue engineering strategies using multipotential cells have been investigated as a therapy for specific neurologic disorders (i.e., paralysis of extremities). Due to the complexity of the architectural organization of the CNS, polymeric scaffolds should provide a suitable 3D carrier for cell delivery. Electrospinning presents a sophisticated technique to fabricate an ECM-like matrix. Recent studies have investigated the potential of electrospun 3D scaffolds, both aligned and non-aligned, in neural tissue engineering using a multipotent neural stem cell (NSC) line, C17-2, derived from a neonatal mouse cerebellum [76, 165]. Yang et al. have investigated the morphology and cell adhesion response of NSC to PLLA non-aligned nanofibrous scaffolds [165]. Phasecontrast microscopy revealed that C17-2 cells seeded on the scaffolds adhered to the scaffolds and started to differentiate on the fibrous scaffold $10 \mathrm{~h}$ after seeding, and by $24 \mathrm{~h}$ around $70 \%$ of cells exhibited a spindle-like shape with extended processes. An additional study by Yang et al. compared the response of C17-2 cells to aligned versus non-aligned electrospun PLLA nanofibers [76], and reported that after 2 days of culture significant changes in the phenotype of cells based on directionality had occurred. 
Successful nerve regeneration is dependent upon extensive growth of axonal processes. The study by Yang et al. found no significant effect of fiber alignment when comparing aligned $(1.5 \mu \mathrm{m})$ and non-aligned $(1.25 \mu \mathrm{m})$ microfibrous scaffolds. However, the directionality did have an effect when comparing aligned (300 nm) and non-aligned $(250 \mathrm{~nm})$ nanofibrous scaffolds. The results indicate that the presence or absence of a directionality effect is dependent on architectural scale. The average neurite length of C17-2 cells on aligned nanofibrous scaffolds was calculated as $100 \mu \mathrm{m}$ and $75-80 \mu \mathrm{m}$ on aligned and non-aligned microfibrous scaffolds, respectively. These results show a significant relationship of a decrease in fiber diameter increasing neurite outgrowth.

\section{4}

\section{Current Challenges and Future Directions}

To date, many different polymers have been successfully electrospun and characterized for numerous intended applications. However, limited progress has been made on fabricating tissues using nanofibrous scaffolds. Unlike nanofiber applications in composites and electronics, tissue engineering applications of nanofibrous polymeric scaffolds still require further extensive biological analyses in addition to physical characterization to determine if they are suitable for the promotion of tissue growth. Recent studies have focused on the introduction of different new polymers for electrospinning, as well as testing and characterizing the physical properties of electrospun nanofibrous polymeric scaffolds, with less emphasis on biological evaluation. To move to the next developmental phase of nanofibrous scaffold-based tissue engineering, cellular and molecular analyses are necessary to understand the interaction between nanofibers and cells. A better understanding of cell-nanofiber interactions, based on the structural and functional similarity between nanofibers and native ECM, is critical to successful tissue engineering.

Functional nanofibrous scaffolds providing structural and mechanical support for tissue growth as well as actively inducing favorable biological activities should be the future aim of research on electrospun nanofibrous scaffolds. Peptide domains, such as RGD on ECM molecules, bind to cell surface receptors, activating cellular signaling pathways to elicit cellular response. Therefore, to promote cellular activities, efforts should be devoted to developing methodologies to incorporate and optimize bioactive motifs or peptides into the electrospun nanofibrous scaffold, ultimately creating biologically active scaffolds. In addition to matrix-bound signal proteins on ECM, soluble bioactive molecules such as growth factors are important for the regulation of cellular events, including proliferation and differentiation [166]. Biodegradable polymers have long been used as drug delivery systems to deliver therapeutic agents because they can be designed to undergo programmed degradation in a controlled fashion [167]. Incorporation of growth factors, such as transforming growth factor-beta (TGF- $\beta$ ) or insulin-like growth factor (IGF), into a nanofibrous scaffold may be used as an additional strategy for the control of tissue growth. Ideally, it is desirable to fabricate nanofibrous scaffolds 
that are capable of releasing, in a controlled manner, one or more growth factors to act on specific cellular functions at different times. A nanofibrous scaffold housing multiple growth factors may be produced using a selected combination of biodegradable polymers, each releasing one or more specifically adsorbed growth factors as a function of its own degradation profile. These characteristics, once optimized and taken together with the "tissue-engineering"-friendly nature of the nanofibrous scaffold, should make this a highly promising candidate scaffold system for tissue regeneration applications.

\section{5}

\section{Conclusion}

Electrospinning technology is a useful, economical, and easily set-up means of fabricating of $3 \mathrm{D}$, highly porous, nanofibrous scaffolds that have been shown to support cellular activities and tissue formation. Conversely, tissue engineering is a revolutionary, cell-based therapy with a higher promise for clinical applications. Together, tissue engineering and regeneration with the application of electrospun polymeric nanofibers is an exciting example of the power of the rapidly emerging field of nanotechnology.

\section{References}

1 Langer R, Vacanti JP. Tissue engineering. Science 1993, 260, 920926.

2 Hutmacher DW. Scaffold design and fabrication technologies for engineering tissues - state of the art and future perspectives. $J$. Biomater. Sci. Polym. Ed. 2001, 12 , 107-124.

3 Lee JH, Jung HW, Kang IK, Lee HB. Cell behaviour on polymer surfaces with different functional groups. Biomaterials 1994, 15, 705-711.

4 Bhardwaj T, Pilliar RM, Grynpas MD, KANDEL RA. Effect of material geometry on cartilagenous tissue formation in vitro. J. Biomed. Mater. Res. 2001, 57, 190-199.

5 ZhANG S. Fabrication of novel biomaterials through molecular selfassembly. Nat. Biotechnol. 2003, 21, 1171-1178.

6 Hersel U, Dahmen C, Kessler H. RGD modified polymers: biomaterials for stimulated cell adhesion and beyond. Biomaterials 2003, 24, 4385-

4415.

7 Flemming RG, Murphy CJ, Abrams GA, Goodman SL, Nealey PF. Effects of synthetic micro- and nanostructured surfaces on cell behavior. Biomaterials 1999, 20, 573-588.

8 Elsdale T, Bard J. Collagen substrata for studies on cell behavior. J. Cell Biol. 1972, 54, 626-637.

9 Cukierman E, Pankov R, Stevens DR, YAMADA KM. Taking cell-matrix adhesions to the third dimension. Science 2001, 294, 1708-1712.

10 Аввотт J, Holtzer H. The loss of phenotypic traits by differentiated cells. 3. The reversible behavior of chondrocytes in primary cultures. J. Cell Biol. 1966, 28, 473-487.

11 Benya PD, Shaffer JD. Dedifferentiated chondrocytes reexpress the differentiated collagen phenotype when cultured in agarose gels. Cell 1982, 30, 215-224.

12 Levenberg S, Huang NF, Lavik E, 
ROGERS AB, ITSKOVITZ-ELDOR J, LANGER R. Differentiation of human embryonic stem cells on threedimensional polymer scaffolds. Proc. Natl. Acad. Sci. U.S.A. 2003, 100, 12 741-12 746.

13 Cukierman E, Pankov R, Yamada KM. Cell interactions with threedimensional matrices. Curr. Opin. Cell Biol. 2002, 14, 633-639.

14 Sinha RK, Morris F, Shah SA, TUAN RS. Surface composition of orthopaedic implant metals regulates cell attachment, spreading, and cytoskeletal organization of primary human osteoblasts in vitro. Clin. Orthop. 1994, 258-272.

15 Dalby MJ, Riehle MO, Johnstone $\mathrm{H}$, Affrossman $\mathrm{S}$, Curtis AS. In vitro reaction of endothelial cells to polymer demixed nanotopography. Biomaterials 2002, 23, 2945-2954.

16 Dalby MJ, Riehle MO, Johnstone HJ, Affrossman S, Curtis AS. Polymer-demixed nanotopography: control of fibroblast spreading and proliferation. Tissue Eng. 2002, 8, 1099-1108.

17 Webster TJ, Siegel RW, Bizios R. Osteoblast adhesion on nanophase ceramics. Biomaterials 1999, 20, 12211227.

18 Webster TJ, Ergun C, Doremus RH, Siegel RW, Bizios R. Enhanced functions of osteoblasts on nanophase ceramics. Biomaterials 2000, 21, 1803 1810.

19 Elias KL, Price RL, Webster TJ. Enhanced functions of osteoblasts on nanometer diameter carbon fibers. Biomaterials 2002, 23, 3279-3287.

20 Huang ZM, Zhang YZ, Kotaki M, RAMAKRISHNA S. A review on polymer nanofibers by electrospinning and their applications in nanocomposites. Composites Sci. Technol. 2003, 63, 2223-2253.

21 Nair LS, Bhattacharyya S, LAURencin CT. Development of novel tissue engineering scaffolds via electrospinning. Expert Opin. Biol. Ther. 2004, 4, 659-668.

22 Li WJ, Mauck RL, Tuan RS. Electrospun nanofibrous scaffolds:
Production, characterization, and applications for tissue engineering and drug delivery. J. Biomed. Nanotechnol. 2005, 1, 259-275.

23 Ma Z, Kotaki M, Inai R, RamaKRISHNA S. Potential of nanofiber matrix as tissue-engineering scaffolds. Tissue Eng. 2005, 11, 101-109.

24 Venugopal J, Ramakrishna S. Applications of polymer nanofibers in biomedicine and biotechnology. Appl. Biochem. Biotechnol. 2005, 125, 147158.

25 Li WJ, Laurencin CT, Caterson EJ, TUAN RS, Ko FK. Electrospun nanofibrous structure: A novel scaffold for tissue engineering. J. Biomed. Mater. Res. 2002, 60, 613-621.

26 Sмітн LA, MA PX. Nano-fibrous scaffolds for tissue engineering. Colloids Surf. B Biointerfaces 2004, 39, 125-131.

27 Whitesides GM, BoncheVA M. Beyond molecules: self-assembly of mesoscopic and macroscopic components. Proc. Natl. Acad. Sci. U.S.A. 2002, 99, 4769-4774.

28 Zhang S, Marini DM, Hwang W, SANTOSo S. Design of nanostructured biological materials through selfassembly of peptides and proteins. Curr. Opin. Chem. Biol. 2002, 6, 865871.

29 Silva GA, Czeisler C, Niece KL, Beniash E, Harrington DA, Kessler JA, Stupp SI. Selective differentiation of neural progenitor cells by highepitope density nanofibers. Science 2004, 303, 1352-1355.

30 Kisiday J, Jin M, Kurz B, Hung H, Semino C, Zhang S, Grodzinsky AJ Self-assembling peptide hydrogel fosters chondrocyte extracellular matrix production and cell division: Implications for cartilage tissue repair Proc. Natl. Acad. Sci. U.S.A. 2002, 99, 9996-10001.

31 Rayleigh JWG. Lond. Edinburgh Dublin Phil. Mag. 1882, 14, 184.

32 Zeleny J. The electrical discharge from liquid points, and a hydrostatic method of measuring the electric intensity at their surface. Phys. Rev. 1914, 3, 69-91. 
33 Zeleny J. Instability of electrified liquid surface. Phys. Rev. 1917, 10, $1-6$.

34 Dole M, Mack LL, Hines RL. Molecular beams of macroions. J. Chem. Phys. 1968, 49, 2240-2249.

35 Vonnegut B, Neubauer RL. J. Colloid Sci. 1952, 7, 616.

36 Drozin VG. The electrical dispersion of liquids as aerosols. J. Colloid Sci. 1955, 7, 616.

37 Patent 1,975,504. 1934.

38 Patent 3,280,229. 1966.

39 Baumgarten PK. Electrostatic spinning of acrylic microfibers. J. Colloid Interface Sci. 1971, 36, 71-79.

40 Larrondo L, Manley RSJ. Electrostatic fiber spinning from polymer melts. 1. Experimentalobservations on fiber formation and properties. J. Polym. Sci. Part B Polym. Phys. 1981, 19, 909-920.

41 Larrondo L, Manley RSJ. Electrostatic fiber spinning from polymer melts. 2. Examination of the flow field in an electrically driven jet. J. Polym. Sci. Part B - Polym. Phys. 1981, 19, 921-932.

42 Larrondo L, Manley RSJ. Electrostatic fiber spinning from polymer melts. 3. Electrostatic deformation of a pendant drop of polymer melt. J. Polym. Sci. Part B - Polym. Phys. 1981, 19, 933940.

43 Kidoaki S, Kwon IK, Matsuda T Mesoscopic spatial designs of nanoand microfiber meshes for tissueengineering matrix and scaffold based on newly devised multilayering and mixing electrospinning techniques. Biomaterials 2005, 26, 37-46.

44 Stankus JJ, Guan J, Fujimoto K, WAGNER WR. Microintegrating smooth muscle cells into a biodegradable, elastomeric fiber matrix. Biomaterials 2006, 27, 735-744.

45 TAYLOR GI. Electrically driven jets. Proc. R. Soc. (London) 1969, 453475.

46 TAYlor GI. Disintegration of water drops in an electric field. Proc. R. Soc. (London) 1964, 383-397.
47 Doshi J, Reneker DH. Electrospinning process and applications of electrospun fibers. J. Electrostatics 1995, 35, 151-160.

48 Fong H, Chun I, Reneker DH. Beaded nanofibers formed during electrospinning. Polymer 1999, 40, 4585-4592.

49 Liv HQ, Hsien YL. Ultrafine fibrous cellulose membranes from electrospinning of cellulose acetate. J. Polym. Sci. Part B - Polym. Phys. 2002, 40, 2119-2129.

50 Deitzel JM, Kleinmeyer J, Harris D, TAN NCB. The effect of processing variables on the morphology of electrospun nanofibers and textiles. Polymer 2001, 42, 261-272.

51 Demir MM, Yilgor I, Yilgor E, ERMAN B. Electrospinning of polyurethane fibers. Polymer 2002, 43, 3303-3309.

52 Zong XH, Kim K, Fang DF, Ran SF, Hsiao BS, Chu B. Structure and process relationship of electrospun bioabsorbable nanofiber membranes. Polymer 2002, 43, 4403-4412.

53 Lee KH, Kim HY, Khil MS, Ra YM, LEE DR. Characterization of nanostructured poly( $\varepsilon$-caprolactone) nonwoven mats via electrospinning. Polymer 2003, 44, 1287-1294.

54 Choi JS, Lee SW, Jeong L, Bae SH, Min BC, Youk JH, Park WH. Effect of organosoluble salts on the nanofibrous structure of electrospun poly(3-hydroxybutyrate-co-3hydroxyvalerate). Int. J. Biol. Macromol. 2004, 34, 249-256.

55 Zong X, Kim K, Fang D, Ran S, Hsiao BS, Chu B. Structure and process relationship of electrospun bioabsorbable nanofiber membranes. Polymer 2002, 43, 4403-4412.

56 Shin YM, Hohman MM, Brenner MP, RUTLEDGe GC. Experimental characterization of electrospinning: The electrically forced jet and instabilities. Polymer 2001, 42, 99559967.

57 Theron A, Zussman E, Yarin AL. Electrostatic field-assisted alignment of electrospun nanofibres. Nanotechnology 2001, 12, 384-390. 
58 Li D, Ouyang G, McCann JT, Xia Y. Collecting electrospun nanofibers with patterned electrodes. Nano Lett. 2005, 5, 913-916.

59 Li WJ, Mauck R, Cooper JA, Tuan RS. Engineering anisotropy in electrospun biodegradable nanofibrous scaffolds for musculoskeletal tissue engineering. In: 5 th Combined Meeting of the Orthopaedic Research Societies of Canada, USA, Japan, and Europe, Banff, Alberta, Canada, 2004.

60 Muschler GF, Nakamoto C, Griffith LG. Engineering principles of clinical cell-based tissue engineering. J. Bone Joint Surg. Am. 2004, 86-A, 1541-1558.

61 Lee YH, Lee JH, An IG, Kim C, Lee DS, LeE YK, NAM JD. Electrospun dual-porosity structure and biodegradation morphology of montmorillonite reinforced PLLA nanocomposite scaffolds. Biomaterials 2005, 26, 3165-3172.

62 Hubbell JA. Biomaterials in tissue engineering. Biotechnology (N Y) 1995, 13, 565-576.

63 TAn EP, Ng SY, Lim CT. Tensile testing of a single ultrafine polymeric fiber. Biomaterials 2005, 26, $1453-$ 1456.

64 Sanders Je, Nicholson BS, Mitchell SB, Ledger RE. Polymer microfiber mechanical properties: A system for assessment and investigation of the link with fibrous capsule formation. J. Biomed. Mater. Res. A 2003, 67, 1412-1416.

65 Grinnell F. Cellular adhesiveness and extracellular substrata. Int. Rev. Cytol. 1978, 53, 65-144.

66 Giancotti FG, Ruoslahti E. Integrin signaling. Science 1999, 285, 10281032.

67 Smetana K, JR. Cell biology of hydrogels. Biomaterials 1993, 14, 1046-1050.

68 Boyan BD, Hummert TW, Dean DD, ScHWARTZ Z. Role of material surfaces in regulating bone and cartilage cell response. Biomaterials 1996, 17, 137146

69 Loeser RF. Chondrocyte integrin expression and function. Biorheology 2000, 37, 109-116.

70 Nikolovski J, Mooney DJ. Smooth muscle cell adhesion to tissue engineering scaffolds. Biomaterials 2000, 21, 2025-2032.

71 Woo KM, Chen VJ, Ma PX. Nanofibrous scaffolding architecture selectively enhances protein adsorption contributing to cell attachment. J. Biomed. Mater. Res. 2003, 67A, 531-537.

72 Buckwalter JA, Mankin HJ. Articular cartilage: Tissue design and chondrocyte-matrix interactions. Instr. Course Lect. 1998, 47, 477-486.

73 Scully SP, Lee JW, Ghert PMA, Qi $\mathrm{W}$. The role of the extracellular matrix in articular chondrocyte regulation. Clin. Orthop. 2001, S72-89.

74 Gray ML, Pizzanelli AM, Grodzinsky AJ, Lee RC. Mechanical and physiochemical determinants of the chondrocyte biosynthetic response. J. Orthop. Res. 1988, 6, 777-792.

75 Li WJ, Jiang YJ, Tuan RS. Chondrocyte phenotype in engineered fibrous matrix is regulated by fiber size. Tissue Eng. in the press.

76 Yang F, Murugan R, Wang S, RAMAKRISHNA S. Electrospinning of nano/micro scale poly(L-lactic acid) aligned fibers and their potential in neural tissue engineering. Biomaterials 2005, 26, 2603-2610.

77 Li WJ, Danielson KG, Alexander PG, Tuan RS. Biological response of chondrocytes cultured in threedimensional nanofibrous poly(epsiloncaprolactone) scaffolds. J. Biomed. Mater. Res. A 2003, 67, 1105-1114.

78 Burdon T, Smith A, Savatier P. Signalling, cell cycle and pluripotency in embryonic stem cells. Trends Cell Biol. 2002, 12, 432-438.

79 Li S, Edgar D, Fassler R, Wadsworth W, Yurchenco PD. The role of laminin in embryonic cell polarization and tissue organization. Dev. Cell 2003, 4, 613-624.

80 Nur-E-Kamal A, Ahmed I, Kamal J, Schindler M, Meiners S. Threedimensional nanofibrillar surfaces promote self-renewal in mouse 
embryonic stem cells. Stem Cells 2005, 24, 426-433.

81 Pittenger MF, Mackay AM, Beck SC, Jaiswal RK, Douglas R, Mosca JD, Moorman MA, SimonetTi DW, Craig S, Marshak DR. Multilineage potential of adult human mesenchymal stem cells. Science $\mathbf{1 9 9 9}$, 284, 143-147.

82 Zuk PA, Zhu M, Mizuno H, Huang J, Futrell JW, Katz AJ, Benhaim P, LORENZ HP, HEDRICK MH.

Multilineage cells from human adipose tissue: Implications for cellbased therapies. Tissue Eng. 2001, 7, 211-228.

83 Goodwin HS, Bicknese AR, Chien SN, BogucKi BD, QUinN CO, WALL DA. Multilineage differentiation activity by cells isolated from umbilical cord blood: Expression of bone, fat, and neural markers. Biol. Blood Marrow Transplant 2001, 7, 581-588.

84 Young He, Steele TA, Bray RA, Hudson J, Floyd JA, Hawkins K, Thomas K, Austin T, Edwards C, Cuzzourt J, Duenzl M, Lucas PA, BLACK AC, JR. Human reserve pluripotent mesenchymal stem cells are present in the connective tissues of skeletal muscle and dermis derived from fetal, adult, and geriatric donors. Anat. Rec. 2001, 264, 51-62.

85 De Bari C, Dell'Accio F, Tylzanowski P, Luyten FP. Multipotent mesenchymal stem cells from adult human synovial membrane. Arthritis Rheum. 2001, 44, 1928-1942.

86 Li WJ, Tuli R, Huang X, LaquerRIERE P, TUAN RS. Multilineage differentiation of human mesenchymal stem cells in a three-dimensional nanofibrous scaffold. Biomaterials 2005, 26, 5158-5166.

87 Schindler M, Ahmed I, Kamal J, Nur EKA, Grafe TH, Young Chung H, Meiners S. A synthetic nanofibrillar matrix promotes in vivolike organization and morphogenesis for cells in culture. Biomaterials 2005, 26, 5624-5631.

88 Nur EKA, Ahmed I, Kamal J, Schindler M, Meiners S. Three dimensional nanofibrillar surfaces induce activation of Rac. Biochem. Biophys. Res. Commun. 2005, 331, 428-434.

89 Frenkel SR, Toolan B, Menche D, Pitman Mi, Pachence JM.

Chondrocyte transplantation using a collagen bilayer matrix for cartilage repair. J. Bone Joint Surg. Br. 1997, 79, 831-836.

90 Lee CR, Grodzinsky AJ, Hsu HP, SpeCtor M. Effects of a cultured autologous chondrocyte-seeded type II collagen scaffold on the healing of a chondral defect in a canine model. J. Orthop. Res. 2003, 21, 272-281.

91 Matthews JA, Wnek GE, Simpson DG, Bowlin GL. Electrospinning of collagen nanofibers. Biomacromolecules 2002, 3, 232-238.

92 Rho KS, Jeong L, Lee G, Seo BM, Park YJ, Hong SD, Roh S, Cho JJ, PARK WH, Min BM. Electrospinning of collagen nanofibers: Effects on the behavior of normal human keratinocytes and early-stage wound healing. Biomaterials 2006, 27, 1452 1461.

93 Telemeco TA, Ayres C, Bowlin GL, Wnek GE, Boland ED, Cohen N, Baumgarten CM, Mathews J, Simpson DG. Regulation of cellular infiltration into tissue engineering scaffolds composed of sumicron diameter fibrils produced by electrospinning. Acta Biomater. 2005, 1, 377-385.

94 Boland ED, Matthews JA, Pawlowski KJ, Simpson DG, WheK GE, Bowlin GL. Electrospinning collagen and elastin: Preliminary vascular tissue engineering. Front Biosci. 2004, 9, 1422-1432.

95 Li M, Mondrinos MJ, Gandhi MR, Ko FK, Weiss AS, Lelkes PI. Electrospun protein fibers as matrices for tissue engineering. Biomaterials 2005, 26, 5999-6008.

96 Matthews JA, Boland ED, Whek GE, Simpson DG, Bowlin GL. Electrospinning of collagen type II: A feasibility study. J. Bioactive Compatible Polymers 2003, 18, 125-134.

97 Shields KJ, Beckman MJ, Bowlin 
GL, WAYNE JS. Mechanical properties and cellular proliferation of electrospun collagen type II. Tissue Eng. 2004, 10, 1510-1517.

98 Ma Z, Kotaki M, Yong T, He W, RAMAKRISHNA S. Surface engineering of electrospun polyethylene terephthalate (PET) nanofibers towards development of a new material for blood vessel engineering. Biomaterials 2005, 26, 2527-2536.

99 Ma Z, He W, Yong T, Ramakrishna S. Grafting of gelatin on electrospun poly(caprolactone) nanofibers to improve endothelial cell spreading and proliferation and to control cell Orientation. Tissue Eng. 2005, 11, 1149-1158.

100 Zhang Y, Ouyang H, Lim CT, RAMAKRISHNA S, HuANG ZM. Electrospinning of gelatin fibers and gelatin/PCL composite fibrous scaffolds. J. Biomed. Mater. Res. B Appl. Biomater. 2005, 72, 156-165.

101 Huang ZM, Zhang YZ, RamaKRISHNA S, LIM CT. Electrospinning and mechanical characterization of gelatin nanofibers. Polymer 2004, 45, 5361-5368.

102 Stitzel J, Liu J, Lee SJ, Komura M, Berry J, Soker S, Lim G, Van Dyke M, Czerw R, Yoo JJ, Atala A. Controlled fabrication of a biological vascular substitute. Biomaterials 2006, 27, 1088-1094.

103 Buttafoco L, Kolkman NG, Engbers-Buijtenhuijs P, Роot AA, Dijkstra PJ, Vermes i, Feijen J. Electrospinning of collagen and elastin for tissue engineering applications. Biomaterials 2006, 27, 724-734.

104 Nagapudi K, Brinkman WT, Thomas bS, Park JO, Srinivasarao M, Wright E, Conticello VP, Chaikof EL. Viscoelastic and mechanical behavior of recombinant protein elastomers. Biomaterials 2005, 26 , 4695-4706.

105 Jin HJ, Fridrikh SV, Rutledge GC, KAPLAN DL. Electrospinning Bombyx mori silk with poly(ethylene oxide). Biomacromolecules 2002, 3, 1233-1239.

106 Jin HJ, Chen J, Karageorgiou V, Altman GH, Kaplan DL. Human bone marrow stromal cell responses on electrospun silk fibroin mats. Biomaterials 2004, 25, 1039-1047.

107 Ohgo K, Zhao C, Kobayashi M, Asaku ra T. Preparation of non-woven nanofibers of Bombyx mori silk, Samia cynthia ricini silk and recombinant hybrid silk with electrospinning method. Polymer 2003, 44, 841-846.

108 Zarkoob S, Eby RK, Reneker DH, Hudson SD, Ertley D, Adams WW. Structure and morphology of electrospun silk nanofibers. Polymer 2004, 45, 3973-3977.

109 Min BM, Lee G, Kim SH, Nam YS, LeE TS, PARK WH. Electrospinning of silk fibroin nanofibers and its effect on the adhesion and spreading of normal human keratinocytes and fibroblasts in vitro. Biomaterials 2004, 25, 1289-1297.

110 Min BM, Jeong L, Nam YS, Kim JM, KIM JY, PARK WH. Formation of silk fibroin matrices with different texture and its cellular response to normal human keratinocytes. Int. J. Biol. Macromol. 2004, 34, 281-288.

111 Park WH, Jeong L, Yoo DI, Hudson S. Effect of chitosan on morphology and conformation of electrospun silk fibroin nanofibers. Polymer 2004, 45, 7151-7157.

112 Silverman RP, Passaretti D, Huang W, Randolph MA, YAREMCHUK MJ. Injectable tissue-engineered cartilage using a fibrin glue polymer. Plast. Reconstr. Surg. 1999, 103, 1809-1818.

113 Worster AA, Brower-Toland BD, Fortier LA, Bent SJ, Williams J, Nixon AJ. Chondrocytic differentiation of mesenchymal stem cells sequentially exposed to transforming growth factor-beta1 in monolayer and insulin-like growth factor-I in a threedimensional matrix. J. Orthop. Res. 2001, 19, 738-749.

114 Fortier LA, Mohammed Ho, Lust G, Nixon AJ. Insulin-like growth factor-I enhances cell-based repair of articular cartilage. J. Bone Joint Surg. Br. 2002, 84, 276-288.

115 Wnek GE, Carr ME, Simpson DG, Bowlin GL. Electrospinning of 
nanofiber fibrinogen structures. Nano Lett. 2003, 3, 213-216.

116 Sechriest VF, Miao YJ, Niyibizi C, Westerhausen-Larson A, Matthew HW, Evans CH, Fu FH, SuH JK. GAG-augmented polysaccharide hydrogel: A novel biocompatible and biodegradable material to support chondrogenesis. J. Biomed. Mater. Res. 2000, 49, 534-541.

117 Lahiji A, Sohrabi A, Hungerford DS, Frondoza CG. Chitosan supports the expression of extracellular matrix proteins in human osteoblasts and chondrocytes. J. Biomed. Mater. Res. 2000, 51, 586-595.

118 Lu JX, Prudhommeaux F, Meunier A, Sedel L, Guillemin G. Effects of chitosan on rat knee cartilages. Biomaterials 1999, 20, 1937-1944.

119 Denuziere A, Ferrier D, Damour O, Domard A. Chitosan-chondroitin sulfate and chitosan-hyaluronate polyelectrolyte complexes: Biological properties. Biomaterials 1998, 19, 1275-1285.

120 Min BM, Lee SW, Lim JN, You Y, Lee TS, KANG PH, PARK WH. Chitin and chitosan nanofibers: Electrospinning of chitin and deacetylation of chitin nanofibers. Polymer 2004, 45, 7137 7142.

121 Subramanian A, Lin Hy, Vu D, LARSEN G. Synthesis and evaluation of scaffolds prepared from chitosan fibers for potential use in cartilage tissue engineering. Biomed. Sci. Instrum. 2004, 40, 117-122.

122 Geng X, Kwon OH, Jang J. Electrospinning of chitosan dissolved in concentrated acetic acid solution. Biomaterials 2005, 26, 5427-5432.

123 Campoccia D, Doherty P, Radice M, Brun P, Abatangelo G, Williams DF. Semisynthetic resorbable materials from hyaluronan esterification. Biomaterials 1998, 19, 2101-2127.

124 Vercruysse KP, MarecaK DM, Marecek JF, Prestwich GD. Synthesis and in vitro degradation of new polyvalent hydrazide crosslinked hydrogels of hyaluronic acid. Bioconjug. Chem. 1997, 8, 686-694.

125 Aigner J, Tegeler J, Hutzler P,
Campoccia D, Pavesio A, Hammer C,

Kastenbauer E, Naumann A.

Cartilage tissue engineering with novel nonwoven structured biomaterial based on hyaluronic acid benzyl ester. J. Biomed. Mater. Res. 1998, 42, 172-181.

126 Grigolo B, Roseti L, Fiorini M, Fini M, Giavaresi G, Aldini NN, Giardino R, FaCchini A. Transplantation of chondrocytes seeded on a hyaluronan derivative (hyaff-11) into cartilage defects in rabbits.

Biomaterials 2001, 22, 2417-2424.

127 Um IC, Fang D, Hsiao BS, Окамото A, Снu B. Electro-spinning and electro-blowing of hyaluronic acid. Biomacromolecules 2004, 5, 1428-1436.

128 Hollinger JO. Preliminary report on the osteogenic potential of a biodegradable copolymer of polyactide (PLA) and polyglycolide (PGA). J. Biomed. Mater. Res. 1983, 17, 71-82.

129 Boland ED, Wnek GE, Simpson DG, Pawlowski KJ, Bowlin GL. Tailoring tissue engineering scaffolds using electrostatic processing techniques: A study of poly(glycolic acid) electrospinning. J. Macromol. Sci. Pure Appl. Chem. 2001, A38, $1231-$ 1243.

130 Boland ED, Telemeco TA, Simpson DG, WNEK GE, BowLIN GL. Utilizing acid pretreatment and electrospinning to improve biocompatibility of poly(glycolic acid) for tissue engineering. J. Biomed. Mater. Res. B Appl. Biomater. 2004, 71, 144-152.

131 Middleton JC, Tipton AJ. Synthetic biodegradable polymers as orthopedic devices. Biomaterials 2000, 21, 23352346.

132 Zong X, Ran S, Kim KS, FAng D, Hsiao BS, Chu B. Structure and morphology changes during in vitro degradation of electrospun poly(glycolide-co-lactide) nanofiber membrane. Biomacromolecules 2003, 4, 416-423.

133 Ko FK, Li WJ, Laurencin CT. Electrospun nanofibrous structure for tissue engineering. In: Sixth World Biomaterials Congress, Kamuela, Hawaii, USA, 2000. 
134 Katti DS, Robinson KW, Ko FK, LAURENCIN CT. Bioresorbable nanofiber-based systems for wound healing and drug delivery: Optimization of fabrication parameters. J. Biomed. Mater. Res. B 2004, 70, 286-296.

135 Berkland C, PaCK DW, Kim KK. Controlling surface nano-structure using flow-limited field-injection electrostatic spraying (FFESS) of poly(D,L-lactide-co-glycolide). Biomaterials 2004, 25, 5649-5658.

136 Piтt CG. Poly-epsilon-caprolactone and its copolymers. In: Biodegradable Polymers as Drug Delivery Systems. Chasin M, Langer R (Eds.), Marcel Dekker, New York, 1990, pp. 71-120

137 Yoshimoto H, Shin YM, Terai H, VACANTI JP. A biodegradable nanofiber scaffold by electrospinning and its potential for bone tissue engineering. Biomaterials 2003, 24, 2077-2082.

138 Shin M, Yoshimoto H, Vacanti JP. In vivo bone tissue engineering using mesenchymal stem cells on a novel electrospun nanofibrous scaffold. Tissue Eng. 2004, 10, 33-41.

139 Shin M, Ishit O, Sueda T, Vacanti JP. Contractile cardiac grafts using a novel nanofibrous mesh. Biomaterials 2004, 25, 3717-3723.

140 Li WJ, Tuli R, Okafor C, Derfoul A, Danielson KG, Hall DJ, Tuan RS. A three-dimensional nanofibrous scaffold for cartilage tissue engineering using human mesenchymal stem cells. Biomaterials 2005, 26, 599-609.

141 Khil MS, Bhattarai SR, Kim HY, Kim SZ, Lee KH. Novel fabricated matrix via electrospinning for tissue engineering. J. Biomed. Mater. Res. B Appl. Biomater. 2004, 72, 117-124.

142 Venugopal J, Ma LL, Yong T, RAMAKRISHNA S. In vitro study of smooth muscle cells on polycaprolactone and collagen nanofibrous matrices. Cell Biol. Int. 2005, 29, 861867.

143 Zhang YZ, Venugopal J, Huang ZM, Lim CT, Ramakrishna S. Characterization of the surface biocompatibility of the electrospun
PCL-collagen nanofibers using fibroblasts. Biomacromolecules 2005, 6, 2583-2589.

144 Venugopal J, Ramakrishna S. Biocompatible nanofiber matrices for the engineering of a dermal substitute for skin regeneration. Tissue Eng. 2005, 11, 847-854.

145 Vaz CM, Tuijl SV, Bouten CVC, BAAIJENS FPT. Design of scaffolds for blood vessel tissue engineering using a multi-layering electrospinning technique. Acta Biomater. 2005, 1, 575-582.

146 Fujihara K, Kotaki M, Ramakrishna S. Guided bone regeneration membrane made of polycaprolactone/ calcium carbonate composite nanofibers. Biomaterials 2005, 26, 41394147.

147 Zong X, Ran S, Fang D, Hsiao BS, CHu B. Control of structure, morphology and property in electrospun poly(glycolide-co-lactide) non-woven membranes via post-draw treatments. Polymer 2003, 44, 49594967.

148 Kenawy el R, Layman JM, Watkins JR, Bowlin GL, Matthews JA, Simpson DG, WheK GE.

Electrospinning of poly(ethylene-covinyl alcohol) fibers. Biomaterials 2003, 24, 907-913.

149 Кнil MS, Сha DI, Кim HY, Кim IS, BhatTARAI N. Electrospun nanofibrous polyurethane membrane as wound dressing. J. Biomed. Mater. Res. B Appl. Biomater. 2003, 67, 675-679.

150 ElisseffF J, Anseth K, Sims D, McIntosh W, Randolph M, LANGeR R. Transdermal photopolymerization for minimally invasive implantation. Proc. Natl. Acad. Sci. U.S.A. 1999, 96, 3104-3107.

151 Elisseeff J, Anseth K, Sims D, McIntosh W, Randolph M, YAREMCHUK M, LANGER R. Transdermal photopolymerization of poly(ethylene oxide)-based injectable hydrogels for tissue-engineered cartilage. Plast. Reconstr. Surg. 1999, 104, 1014-1022.

152 Huang L, Nagapudi K, Apkarian RP, СНАI коF EL. Engineered collagen- 
PEO nanofibers and fabrics. $J$. Biomater. Sci. Polym. Ed. 2001, 12, 979-993.

153 Duan B, Dong C, Yuan X, Yao K. Electrospinning of chitosan solutions in acetic acid with poly(ethylene oxide). J. Biomater. Sci. Polym. Ed. 2004, 15, 797-811.

154 Zong X, Li S, Chen E, Garlick B, Kim KS, Fang D, Chiu J, Zimmerman T, Brathwaite C, Hsiao BS, Chu B. Prevention of postsurgeryinduced abdominal adhesions by electrospun bioabsorbable nanofibrous poly(lactide-co-glycolide)-based membranes. Ann. Surg. 2004, 240, 910-915.

155 Kenawy el R, Bowlin GL, Mansfield K, Layman J, Simpson DG, Sanders EH, WNEK GE. Release of tetracycline hydrochloride from electrospun poly(ethylene-co-vinylacetate), poly(lactic acid), and a blend. J. Controlled Release 2002, 81, 57-64.

156 Ding B, Kimura E, Sato T, Fujita S, Shiratori S. Fabrication of blend biodegradable nanofibrous nonwoven mats via multi-jet electrospinning. Polymer 2004, 45, 1895-1902.

157 He W, Ma Z, Yong T, Teo WE, RAMAKRISHNA S. Fabrication of collagen-coated biodegradable polymer nanofiber mesh and its potential for endothelial cells growth. Biomaterials 2005, 26, 7606-7615.

158 Min BM, You Y, Kim JM, Lee SJ, PARK WH. Formation of nanostructured poly(lactic-co-glycolic acid)/ chitin matrix and its cellular response to normal human keratinocytes and fibroblasts. Carbohydr. Polymers 2004, 57, 285-292.

159 Xu C, YANG F, Wang S, Ramakrishna S. In vitro study of human vascular endothelial cell function on materials with various surface roughness. $J$. Biomed. Mater. Res. A 2004, 71, 154161.

160 Xu CY, Inai R, Kotaki M, RamakRISHnA S. Aligned biodegradable nanofibrous structure: A potential scaffold for blood vessel engineering. Biomaterials 2004, 25, 877-886.

161 Riboldi SA, Sampaolesi M, Neuenschwander P, Cossu G,
References 185

Mantero S. Electrospun degradable polyesterurethane membranes: Potential scaffolds for skeletal muscle tissue engineering. Biomaterials 2005, 26, 4606-4615.

162 Neumann T, Hausch Ka SD, Sanders JE. Tissue engineering of skeletal muscle using polymer fiber arrays. Tissue Eng. 2003, 9, 995-1003.

163 Cronin EM, Thurmond FA, BasselDuby R, Williams RS, Wright WE, Nelson KD, Garner HR. Proteincoated poly(L-lactic acid) fibers provide a substrate for differentiation of human skeletal muscle cells. $J$. Biomed. Mater. Res. A 2004, 69, 373381.

164 Lee CH, Shin HJ, Cho IH, Kang YM, Kim IA, PARK KD, SHIN JW. Nanofiber alignment and direction of mechanical strain affect the ECM production of human ACL fibroblast. Biomaterials 2005, 26, 1261-1270.

165 Yang F, Xu CY, Kotaki M, Wang S, RAMAKRISHNA S. Characterization of neural stem cells on electrospun poly(L-lactic acid) nanofibrous scaffold. J. Biomater. Sci. Polym. Ed. 2004, 15, 1483-1497.

166 Tatsuyama K, Maezawa Y, Baba $\mathrm{H}$, Imamura Y, Fukuda M. Expression of various growth factors for cell proliferation and cytodifferentiation during fracture repair of bone. Eur. J. Histochem. 2000, 44, 269-278.

167 Kost J, LaNGer R. Responsive polymeric delivery systems. Adv. Drug Deliv. Rev. 2001, 46, 125-148.

168 Boland ED, Telemeco TA, Simpson DG, Wnek GE, Bowlin GL. Utilizing acid pretreatment and electrospinning to improve biocompatibility of poly(glycolic acid) for tissue engineering. J. Biomed. Mater. Res. B 2004, 71, 144-152.

169 Bini TB, Gao S, Xu X, Wang S, Ramakrishna $S$, Leong KW. Peripheral nerve regeneration by microbraided poly(L-lactide-coglycolide) biodegradable polymer fibers. J. Biomed. Mater. Res. A 2004, 68, 286-295.

170 Zhang Y, OuYang H, Lim CT, Ramakrishna S, Huang ZM. 
Electrospinning of gelatin fibers and gelatin/PCL composite fibrous scaffolds. J. Biomed. Mater. Res. B 2005, 72, 156-165.

171 Fertala A, Han WB, Ko FK. Mapping critical sites in collagen II for rational design of gene-engineered proteins for cell-supporting materials. J. Biomed. Mater. Res. 2001, 57, 48-58.

172 Yang F, Murugan R, Wang S, RAMAKRISHNA S. Electrospinning of nano/micro scale poly(L-lactic acid) aligned fibers and their potential in neural tissue engineering. Biomaterials 2005, 26, 2603-2610.

173 Xu C, Yang F, Wang S, RamakRISHNA S. In vitro study of human vascular endothelial cell function on materials with various surface roughness. J. Biomed. Mater. Res. A 2004, 71, 154-161.

174 Zong X, Bien H, Chung CY, Yin L, Fang D, Hsiao BS, Chu B, Entcheva E. Electrospun fine-textured scaffolds for heart tissue constructs. Biomaterials 2005, 26, 5330-5338.

175 Kim K, Yu M, Zong X, Chiu J, Fang D, Seo YS, Hsiao BS, Chu B, Hadjiargyrou M. Control of degradation rate and hydrophilicity in electrospun non-woven poly(D,Llactide) nanofiber scaffolds for biomedical applications. Biomaterials 2003, 24, 4977-4985.

176 Badami AS, Kreke MR, Thompson MS, Riffle JS, Goldstein AS. Effect of fiber diameter on spreading, proliferation, and differentiation of osteoblastic cells on electrospun poly(lactic acid) substrates. Biomaterials 2006, 27, 596-606.

177 Lee YH, Lee JH, An IG, Kim C, Lee DS, LeE YK, Nam JD. Electrospun dual-porosity structure and biodegradation morphology of Montmorillonite reinforced PLLA nanocomposite scaffolds. Biomaterials 2005, 26, 31653172.

178 Mo XM, Xu CY, КотAKI M, RAMAKRISHNa S. Electrospun P (LLA-CL) nanofiber: A biomimetic extracellular matrix for smooth muscle cell and endothelial cell proliferation. Biomaterials 2004, 25, 1883-1890.
179 Xu C, Inai R, Kotaki M, RAMAKRISHNA S. Electrospun nanofiber fabrication as synthetic extracellular matrix and its potential for vascular tissue engineering. Tissue Eng. 2004, 10, 1160-1168.

180 Inoguchi H, Kwon IK, Inoue E, Takamizawa K, Maehara Y, Matsuda T. Mechanical responses of a compliant electrospun poly(1-lactideco-epsilon-caprolactone) smalldiameter vascular graft. Biomaterials 2006, 27, 1470-1478.

181 Kwon IK, Kidoaki S, Matsuda T. Electrospun nano- to microfiber fabrics made of biodegradable copolyesters: Structural characteristics, mechanical properties and cell adhesion potential. Biomaterials 2005, 26, 3929-3939.

182 Chua KN, Lim WS, Zhang P, Lu H, Wen J, Ramakrishna S, Leong KW, MAO HQ. Stable immobilization of rat hepatocyte spheroids on galactosylated nanofiber scaffold. Biomaterials 2005, 26, 2537-2547.

183 Nair LS, Bhattacharyya S, Bender JD, Greish Ye, Brown PW, Allcock HR, LAURENCIN CT. Fabrication and optimization of methylphenoxy substituted polyphosphazene nanofibers for biomedical applications. Biomacromolecules 2004, 5, 22122220.

184 Lee IS, Kwon OH, Meng W, Kang IK. Nanofabrication of microbial polyester by electrospinning promotes cell attachment. Macromol. Res. 2004, 12, 374-378.

185 Ito Y, Hasuda H, Kamitakahara M, Ohtsuki C, Tanihara M, Kang IK, Kwon OH. A composite of hydroxyapatite with electrospun biodegradable nanofibers as a tissue engineering material. J. Biosci. Bioeng. 2005, 100, 43-49.

186 Stankus JJ, Guan J, Wagner WR. Fabrication of biodegradable elastomeric scaffolds with sub-micron morphologies. J. Biomed. Mater. Res. A 2004, 70, 603-614.

187 Bhattarai SR, Bhattarai N, Yi HK, Hwang PH, Cha DI, Kim HY. Novel biodegradable electrospun membrane: 
Scaffold for tissue engineering. Biomaterials 2004, 25, 2595-2602.

188 Khil MS, Сha DI, Кim HY, Кim IS, BHATTARAI N. Electrospun nanofibrous polyurethane membrane as wound dressing. J. Biomed. Mater. Res. B 2003, 67, 675-679.

189 Matsuda T, Ihara M, Inoguchi H, Kwon IK, Takamizawa K, Kidoaki S. Mechano-active scaffold design of small-diameter artificial graft made of electrospun segmented polyurethane fabrics. J. Biomed. Mater. Res. A 2005, 73, 125-131.

190 Kidoaki S, Kwon IK, Matsuda T. Structural features and mechanical properties of in situ-bonded meshes of segmented polyurethane electrospun from mixed solvents. J. Biomed. Mater. Res. B Appl. Biomater. 2006, 76, 219229.

191 Ma Z, Kotaki M, Yong T, He W, RAMAKRISHNA S. Surface engineering of electrospun polyethylene terephthalate (PET) nanofibers towards development of a new material for blood vessel engineer- ing. Biomaterials 2005, 26, 25272536.

192 Sun T, Mai S, Norton D, Haycock JW, Ryan AJ, MacNeil S. Selforganization of skin cells in threedimensional electrospun polystyrene scaffolds. Tissue Eng. 2005, 11, $1023-$ 1033.

193 Boland ED, Coleman BD, Barnes CP, Simpson DG, WNeK GE, Bowlin GL. Electrospinning polydioxanone for biomedical applications. Acta Biomater. 2005, 1, 115-123.

194 Casper Cl, Yamaguchi N, Kiick KL, RABOLt JF. Functionalizing electrospun fibers with biologically relevant macromolecules. Biomacromolecules 2005, 6, 1998-2007.

195 Bhattarai N, Edmondson D, Veiseh O, Matsen FA, Zhang M. Electrospun chitosan-based nanofibers and their cellular compatibility. Biomaterials 2005, 26, 6176-6184.

196 Son WK, Youk JH, Park WH. Preparation of ultrafine oxidized cellulose mats via electrospinning. Biomacromolecules 2004, 5, 197-201. 